\title{
Lighting, density, and dietary strategies to improve poultry behavior, health, and production
}

\author{
Karim El-Sabrout ${ }^{a *}$ (iD | Ahmed El-Deek ${ }^{\text {(iD) | Sohail Ahmad }}{ }^{b}$ (D) Muhammad Usman ${ }^{b}$ | \\ Maiko Roberto Tavares Dantas ${ }^{(i D}$ | João Batista Freire Souza-Junior (iD
}

aDepartment of Poultry Production, Faculty of Agriculture (El-Shatby), Alexandria University, Alexandria, Egypt.

Department of Poultry Production, Faculty of Animal Production and Technology, University of Veterinary and Animal Sciences, Lahore, Pakistan.

Laboratory of Biometeorology and Environmental Biophysics, Federal Rural University of Semi-Arid, Mossoró, RN, Brazil.

Department of Animal Science, Federal University of Ceara, Fortaleza, CE, Brazil.

Corresponding author: kareem.badr@alexu.edu.eg

\begin{abstract}
Poultry production is the most rapidly expanding agricultural industry. Consumer awareness of animal welfare has grown in recent years, and as a result, consideration for higher-quality meat production has increased. Environmental changes impact agricultural activity, including poultry production. These changes have raised serious worries that will severely impact poultry health and productivity due to climate change. In light of current environmental changes, determining the ideal environmental conditions for animals is a difficult challenge for researchers and breeders. When investigating the best environmental conditions for better poultry rearing and production, we must consider lighting, density, and dietary factors. These factors have separate and interactive effects on birds' behavior and performance. Understanding animal behavior is a key criterion for assessing animal welfare. It can assist breeders in better managing farm animals by reflecting the adaptability of the animal body to the surrounding environmental conditions. However, the optimal light quality and quantity, density, and feeding levels for poultry farming, particularly for chickens, are still a source of considerable debate among researchers and breeders. Therefore, this review discussed the current practical strategies for improving poultry behavior, health, and production through lighting, density, and feeding factors.
\end{abstract}

Keywords: animal husbandry, bird, feeding, lighting color, welfare

\section{Introduction}

Environmental changes impact agricultural activity, including poultry production. These changes have raised serious worries that will severely impact poultry health and productivity due to the current climate change. Poultry production is the most rapidly expanding agricultural industry. It is generally categorized into meat and egg products (Ren et al 2020). Based on FAO's reports, worldwide meat demand is expected to rise by $40 \%$ by 2030 , compared to average 2005-2007 levels, reaching over 400 million tonnes, to meet the world's growing population and increased meat consumption. According to recent OECD-FAO statistics, global meat output (poultry, beef, sheep, among others) would increase by approximately $35 \%$ by 2030 , with demand for poultry meat increasing by $50 \%$, the majority coming from developing countries.

Poultry production can be accelerated to understand better appropriate circumstances for avian behavior, health, and welfare. Consumer awareness of avian health and welfare has grown in recent years, and as a result, consideration for higher-quality meat production has increased. Concerns about animal welfare continue to be an interesting issue for researchers, breeders, and animal rights organizations. On the other hand, breeders must adopt innovative technologies that can help them to increase production at a lower cost and with fewer negative environmental consequences to meet that demand. Most of these technologies aim to improve traditional inputs, including lighting, density, and feeding.

Determining the ideal environmental conditions for animals, in light of current environmental changes, is a difficult challenge for researchers and breeders. For animals to express their maximum genetic potential, they must be exposed to ideal environmental conditions. Recommendations for optimal environmental factors (light, temperature, humidity, ventilation, among others) are critical to increasing profitability and decreasing physiological stress in birds. When investigating the ideal environmental conditions for better poultry rearing, we must consider dietary, density, and lighting factors. Lighting, density, and feeding all have separate and interactive effects on bird's performance (Figure 1). However, the optimal light quality and quantity for poultry farming, as well as density and feeding levels, particularly for chickens, are still a source of considerable debate among researchers and breeders. Thus, this review presents a comprehensive overview of current practical strategies for improving poultry behavior, health, and production through lighting, density, and feeding factors. 

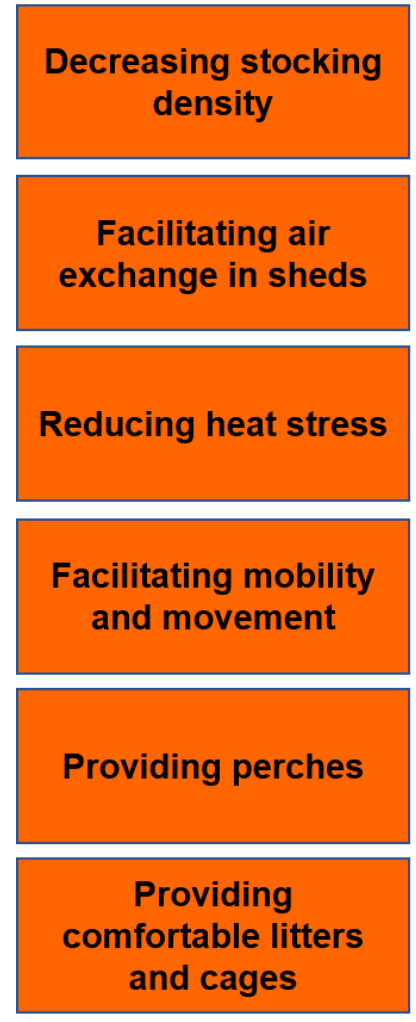
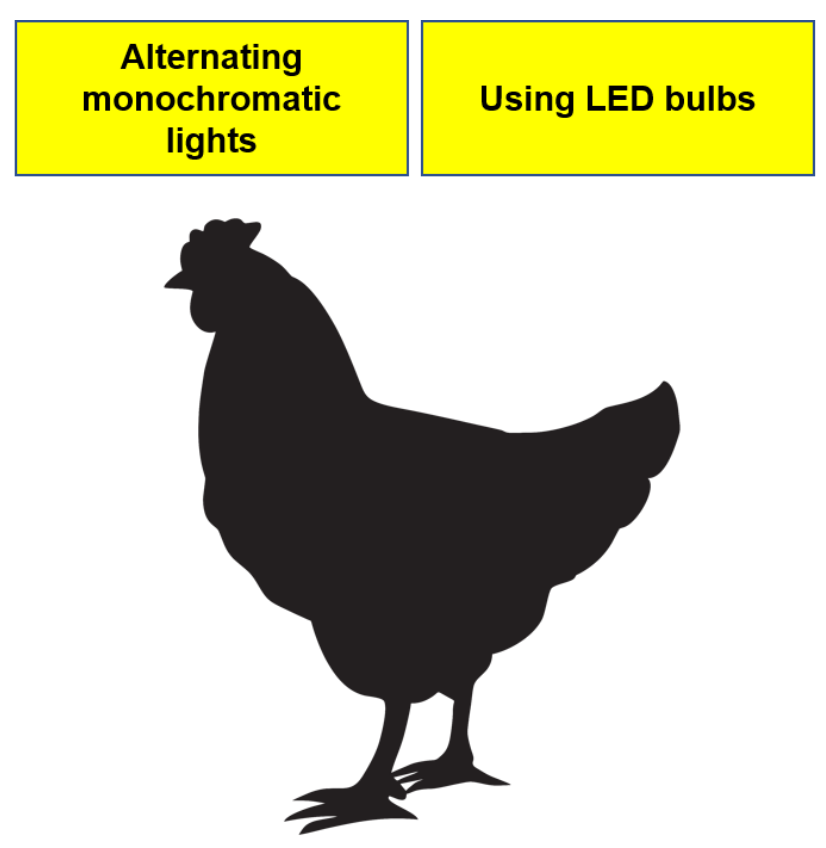

Using nutraceuticals as feed additives

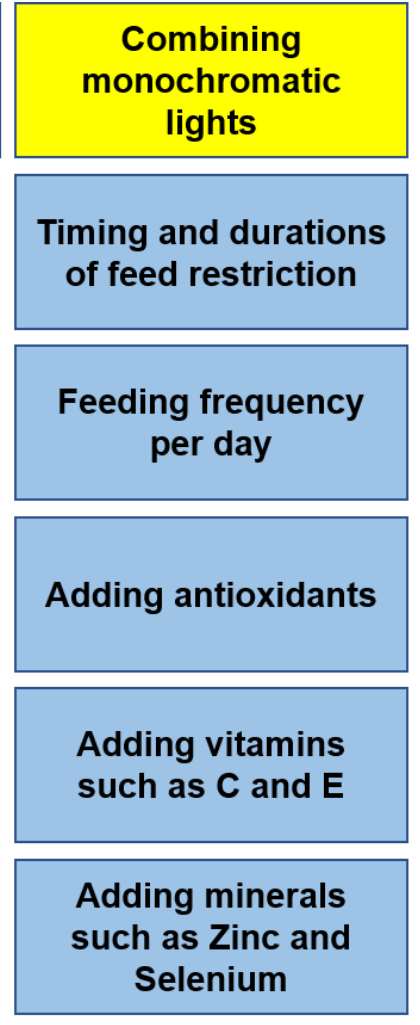

Combining lights

Figure 1 Practical husbandry strategies to improve poultry behavior, health, and production.
2. Lighting strategies to improve poultry behavior, health, and production

Lighting is an essential environmental component in poultry housing systems. It is a powerful exogenous factor with direct and indirect impacts on poultry raising and productivity (Table 1). It influences poultry growth, development, and productive performance (Lewis and Morris 1998; Soliman and El-Sabrout 2020). Additionally, it is an important microclimate factor that significantly impacts poultry behavioral activities (walking, foraging, drinking, among others), physiological functioning (digestive, reproduction, among others), and immunological response (health) (Yang et al 2016; Soliman and El-Sabrout 2020). It has also been found that light is very critical in the whole chick's life, from incubation through marketing. Good light programming enhances birds' behavior, health, feed intake, productivity (body weight), and well-being, resulting in more profitable production.

Light penetrates through the eyes and the top of the skull in birds via the pineal gland and the pituitary gland next to the hypothalamus (Soliman and El-Sabrout 2020) (Figure 2). In comparison to humans, birds have superior visual abilities, including the ability to perceive a wide range of colors (Prescott et al 2003). Bird visible light has a wavelength range of $380 \mathrm{~nm}$ to $740 \mathrm{~nm}$, falling between invisible infrared (longer wavelengths) and invisible ultraviolet (shorter wavelengths) light rays, according to Parvin et al (2014). According to Lewis and Gous (2009), birds can perceive ultraviolet light below $400 \mathrm{~nm}$ in addition to the human range $(400-750 \mathrm{~nm})$. Lewis and Morris (2006) reported three primary elements influencing poultry's vision: retinal, pineal gland, and hypothalamus characteristics. The retina guarantees that birds can clearly see their surroundings and behave appropriately, as well as that the effects of light are directed toward growth and behavior (Wilson and Lindstrom 2011).

The bird's circadian rhythm serves in the optimization of its metabolism, physiology, and behavioral pattern. Light assists the bird in establishing rhythmicity and synchronizing numerous vital functions, such as body temperature and various metabolic steps that improve feeding and digestion (Pal et al 2019). Light also promotes the secretion of hormones involved in the development, maturation, and reproduction (Olanrewaju et al 2016; Yang et al 2016). It mainly affects the pineal gland, aiding in synchronizing circadian rhythms and limiting melatonin release (Deep et al 2012).

Since 1950, house lighting systems have promoted bird growth and development (Cao et al 2012). Artificial lighting has been utilized in poultry farming to influence physiological responses and metabolism, and increase productivity. Light wavelength (color), intensity (brightness), and lighting duration (photoperiod) are the three primary components of artificial lighting (Wei et al 2020; Soliman and El-Sabrout 2020). The effect of light is caused by a combination of light sources, intensity, color, and photoperiod regimen (Parvin et al 2014; Wei et al 2020). Light quantity (intensity) and quality (color) are two significant factors influencing poultry behavior and productivity (Parvin et al 2014; Elkomy et al 2019; Soliman and El-Sabrout 2020). 
In general, various researches have been conducted to investigate the effects of light intensity, source, and color on poultry performance (Parvin et al 2014; Borille et al 2015;
Soliman and El-Sabrout 2020; Wei et al 2020), but the optimal light color and intensity for poultry, particularly chickens, is still a source of considerable debate.

Table 1 The main results regarding lighting aspects on improving poultry behavior, health, and production.

\begin{tabular}{|c|c|c|c|c|}
\hline $\begin{array}{l}\text { Effect-causing } \\
\text { agents }\end{array}$ & Evaluated variables & Species & Main results & References \\
\hline $\begin{array}{l}\text { Different lights } \\
\text { warmth }\end{array}$ & $\begin{array}{l}\text { Performance and } \\
\text { preference }\end{array}$ & $\begin{array}{l}\text { Broiler } \\
\text { chickens }\end{array}$ & $\begin{array}{l}\text { The body weight in cool-warm LED treatment was greater than } \\
\text { warm-warm LED, while cool-cool were intermediate. There was no } \\
\text { effect of treatment on feed: gain in either trial. Birds in the cool- } \\
\text { warm treatment exhibited a clear preferential pattern for warm light }\end{array}$ & $\begin{array}{l}\text { Aldridge et } \\
\text { al (2021) }\end{array}$ \\
\hline $\begin{array}{l}\text { Different white } \\
\text { light LED }\end{array}$ & $\begin{array}{l}\text { Hatchability and chick } \\
\text { quality }\end{array}$ & $\begin{array}{l}\text { Broiler } \\
\text { chickens and } \\
\text { chicks }\end{array}$ & $\begin{array}{l}\text { The blue and red lights treatments could be used to improve } \\
\text { hatchability and chick quality in broiler chickens }\end{array}$ & $\begin{array}{l}\text { Archer } \\
(2018)\end{array}$ \\
\hline Lighting stress & $\begin{array}{l}\text { Fluctuating asymmetry, } \\
\text { heterophil-to- } \\
\text { lymphocyte ratio, and } \\
\text { tonic immobility duration }\end{array}$ & $\begin{array}{l}\text { Broiler } \\
\text { chickens }\end{array}$ & $\begin{array}{l}\text { There was a significant difference between the heterophil-to- } \\
\text { lymphocyte ratio and the tonic immobility duration between birds } \\
\text { housed in continuous light ( } 24 \mathrm{~L}: 0 \mathrm{D}) \text { and a light-dark regimen } \\
\text { (14L:10D). Results indicate that a continuous light regimen seriously } \\
\text { negatively affects the welfare of birds. }\end{array}$ & $\begin{array}{l}\text { Campo et } \\
\text { al (2007) }\end{array}$ \\
\hline \multirow[t]{2}{*}{ Light intensity } & $\begin{array}{l}\text { Behavior and diurnal } \\
\text { rhythms }\end{array}$ & $\begin{array}{l}\text { Broiler } \\
\text { chickens }\end{array}$ & $\begin{array}{l}\text { Light intensity ranges from } 1 \text { to } 40 \text { Ix did not affect melatonin levels } \\
\text { or diurnal behavioral rhythms. Birds exposed to a light intensity of } 1 \\
\text { Ix rested more and preened less, indicating a reduced welfare state }\end{array}$ & $\begin{array}{l}\text { Deep et al } \\
\text { (2012) }\end{array}$ \\
\hline & $\begin{array}{l}\text { Reproductive and } \\
\text { productive performance }\end{array}$ & Japanese quail & $\begin{array}{l}\text { The exposure to } 0.6 \text { Ix caused a significant decrease in sperm count } \\
\text { and live sperm percentage, and increased dead sperm percentage. } \\
\text { The application to program } 0.6 \text { Ix causes an increase in stress index. } \\
\text { The best feed conversion ratio was detected in normal daylight, } 0.6 \\
\text { Ix and } 25 \mathrm{Ix} \text {, respectively }\end{array}$ & $\begin{array}{l}\text { Maty et al } \\
(2021)\end{array}$ \\
\hline $\begin{array}{l}\text { Monochromatic } \\
\text { red and blue light }\end{array}$ & $\begin{array}{l}\text { Physiological and } \\
\text { behavioral parameters }\end{array}$ & $\begin{array}{l}\text { Broiler } \\
\text { chickens }\end{array}$ & $\begin{array}{l}\text { The red and blue monochromatic light during incubation can } \\
\text { differently program the post embryonic development of broilers } \\
\text { with possible consequences for their growth and welfare }\end{array}$ & $\begin{array}{l}\text { Drozdová } \\
\text { et al (2021) }\end{array}$ \\
\hline \multirow[t]{4}{*}{$\begin{array}{l}\text { Different light } \\
\text { colors }\end{array}$} & $\begin{array}{l}\text { Growth and reproduction } \\
\text { performance }\end{array}$ & Japanese quails & $\begin{array}{l}\text { Quails reared under red color light had higher body weight at five } \\
\text { weeks of age, relative growth rate, the first } 42 \text { days of egg } \\
\text { production, relative ovaries and testicle weights, sperm motility and } \\
\text { fertility, and hatchability percentages than those raised under green } \\
\text { and white light colors }\end{array}$ & $\begin{array}{l}\text { Elkomy et } \\
\text { al (2019) }\end{array}$ \\
\hline & $\begin{array}{l}\text { Egg-laying performance, } \\
\text { egg qualities, blood } \\
\text { hormone levels, and } \\
\text { behavior patterns }\end{array}$ & $\begin{array}{l}\text { Brown Tsaiya } \\
\text { ducks }\end{array}$ & $\begin{array}{l}\text { The applying red light illumination in the indoor laying duck raising } \\
\text { system with positive results on egg-laying performance and } \\
\text { acceptable egg weight, equivalent egg qualities compared to white } \\
\text { and blue light }\end{array}$ & $\begin{array}{l}\text { Su et al } \\
(2021)\end{array}$ \\
\hline & $\begin{array}{l}\text { Production and egg } \\
\text { quality }\end{array}$ & Laying hens & $\begin{array}{l}\text { The different colors of light sources (blue, yellow, green, red, and } \\
\text { white) did not affect production parameters or egg quality. }\end{array}$ & $\begin{array}{l}\text { Borille et al } \\
\text { (2015) }\end{array}$ \\
\hline & Drinking behavior & Layer pullets & $\begin{array}{l}\text { The pullets preferred to drink under the blue light the first six hours } \\
\text { after the lights came on and under the white light within the last six } \\
\text { hours before the lights went off }\end{array}$ & $\begin{array}{l}\text { Li et al } \\
(2020)\end{array}$ \\
\hline $\begin{array}{l}\text { Fluorescent lights } \\
\text { and LED lights }\end{array}$ & $\begin{array}{l}\text { Production performance } \\
\text { and egg quality }\end{array}$ & Laying hens & $\begin{array}{l}\text { The emerging poultry-specific LED lights yield comparable } \\
\text { production performance and egg quality of W-36 laying hens to the } \\
\text { traditional fluorescent lights. }\end{array}$ & $\begin{array}{l}\text { Liu et al } \\
(2018)\end{array}$ \\
\hline $\begin{array}{l}\text { LED bulbs and CFL } \\
\text { bulbs }\end{array}$ & Growth, Stress, and Fear & Broiler chicken & $\begin{array}{l}\text { LEDs result in better well-being and feed conversion when compared } \\
\text { to CFLs bulbs. LEDs show improved production and well-being of } \\
\text { broiler chickens compared to CFLs bulbs }\end{array}$ & $\begin{array}{l}\text { Huth and } \\
\text { Archer } \\
\text { (2015) }\end{array}$ \\
\hline \multirow[t]{3}{*}{$\begin{array}{l}\text { Combinations of } \\
\text { lights colors }\end{array}$} & $\begin{array}{l}\text { Growth and productive } \\
\text { performance }\end{array}$ & $\begin{array}{l}\text { Broiler } \\
\text { chickens }\end{array}$ & $\begin{array}{l}\text { An environment under combinations of monochromatic lights of } \\
\text { Green-Blue and Blue-Green exchanges can be used successfully to } \\
\text { improve growth and productive performance in broilers }\end{array}$ & $\begin{array}{l}\text { Cao et al } \\
(2012)\end{array}$ \\
\hline & $\begin{array}{l}\text { Blood, skeletal } \\
\text { development, and sexual } \\
\text { development parameters }\end{array}$ & Laying hens & $\begin{array}{l}\text { An appropriately staged spectral control using LED lights could } \\
\text { positively affect the immune performance, bone development, and } \\
\text { production performance of caged layer chickens during their } \\
\text { brooding and rearing periods. }\end{array}$ & $\begin{array}{l}\text { Wei et al } \\
(2020)\end{array}$ \\
\hline & $\begin{array}{l}\text { Growth and immune } \\
\text { response }\end{array}$ & $\begin{array}{l}\text { Broilers } \\
\text { chickens }\end{array}$ & $\begin{array}{l}\text { The best results observed were in Green Light } \times \text { Blue Light on } \\
\text { performance, hematological parameters, biochemical parameters, } \\
\text { tonic immobility duration, and open field test. }\end{array}$ & $\begin{array}{l}\text { Seo et al } \\
(2016)\end{array}$ \\
\hline
\end{tabular}

Birds use scanning behavior to collect visual data to make choices and decisions, such as seeking food (Fernández-Juricic et al 2004). Ultraviolet (UV) exposure, in general, influences bird development by promoting cholecalciferol synthesis in the skin (vitamin $D_{3}$ ). Light has been shown to improve feed intake, growth, and immunity in 
birds (Huth and Archer 2015; Soliman and El-Sabrout 2020). With the aim of improved poultry welfare and optimum production, UV light usage in poultry production is gaining traction. Poultry can see in the UVA wavelengths (320-400 $\mathrm{nm}$ ) that encourage birds to express their natural behavioral activities such as foraging, drinking, walking, ground-pecking, and preening as well as dust-bathing. They also need the supplementation of UVB wavelengths (280-315 nm) which have physiological influences by stimulating vitamin $D$ pathways, promoting skeletal development and growth, and impacting egg production (Rana and Campbell 2021). Therefore, the provision of UVA and UVB lights in poultry housing is important for improving poultry behavior, welfare, and productivity. Nevertheless, the optimal duration of UVB exposure in poultry farms and the possible adverse effects of UVB lights on birds are still being debated and require additional research investigations.

Light is a crucial environmental factor that affects bird behavior, development, production performance, health, and well-being (Parvin et al 2014; Soliman and El-Sabrout 2020). The emerging light-emitting diode (LED) lighting in poultry housing has drawn increasing attention from scientific and industrial communities. More energy-efficient, durable, affordable, and dimmable LED lights are increasingly finding applications in poultry production. LED light bulbs are becoming more used in poultry farms because, unlike CFL (compact fluorescent lamp), they are dimmable and even more energy-efficient than CFLs. They have increased energy savings in commercial poultry farming and positively affect the bird's growth and well-being (Huth and Archer 2015; Olanrewaju et al 2018). LEDs can result in better feed conversion and well-being when compared to CFLs. It is also notable that there are various types of LED bulbs, but they did not have the same effects on the bird performance, likely due to the spectrum of light each creates. In general, LED lighting can reduce stress and fear in reared birds compared to other traditional lightings (Mohamed et al 2014), and enhance their well-being. Reduced stress and fear responses may result in minor bird injury during handling and transportation. The reduced effect of stressors permits the bird to develop more efficiently and productively. In addition, Liu et al (2018) indicated that LED lights could be a viable replacement to traditional lighting in sustaining laying hen production performance.

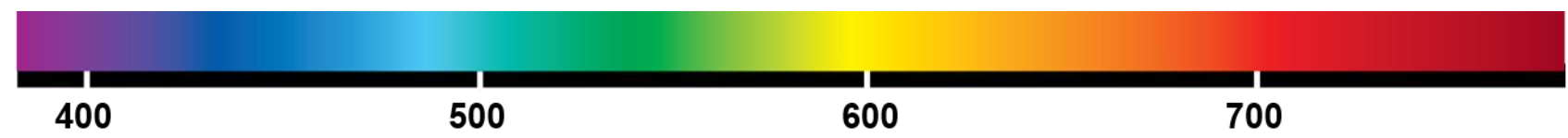

Short

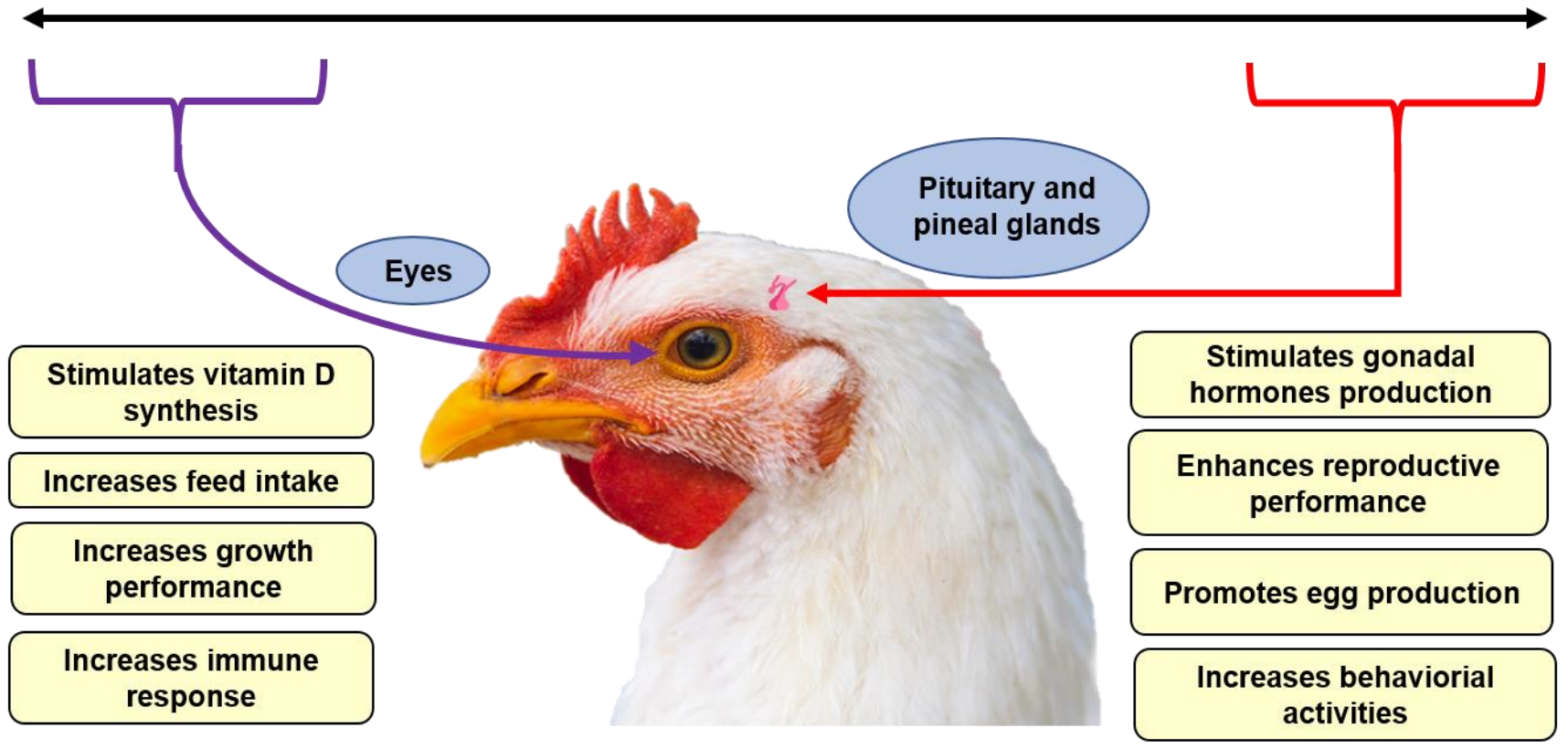

Figure 2 Potential physiological, behavioral, and productive responses of birds to a light stimulus.

\subsection{Light color (wavelength)}

As one of the primary light components that affects lighting quality, light color is determined by wavelength and has varying impacts on poultry performance and welfare. Several investigations using monochromatic light from LED bulbs have been conducted. Arbor Acres male broilers reared under combinations of monochromatic lights (white-blue, red-blue, green-blue, blue-green) exhibited superior growth and development than those reared under white lighting (Cao et al 2012). A mixture of monochromatic lights can be used successfully to promote growth and productive performance in broilers, resulting in higher body weight $(>10 \%)$ and carcass ( $>25 \%)$ with a lower feed conversion ratio 
(>15\%). Oke et al (2021a) observed that switching from green to blue light at four weeks of age promoted ideal behavior and stimulated growth in broilers. On the other hand, Drozdová et al (2021) have investigated the exposure of fertilized chicken eggs under monochromatic red (632 nm) and blue (463 nm) light during incubation. They found that chick embryos incubated under red lighting had a higher body weight than those incubated under blue lighting, particularly during the rapid growth phase (days 18, 20, and 21 of age). The increased growth rate was related to behavioral features, primarily because embryos incubated under red lighting exhibited more passive (resting, standing, preening, dustbathing) and less active behaviors (walking, foraging, fighting, wing-flapping) than embryos incubated under blue lighting.

Blue and red lighting had a significantly increased hatchability of fertile eggs $(>5 \%)$ compared with the dark commercial treatment (Archer 2018). Furthermore, Sabuncuoglu et al (2018) found that blue and green LED lightings used on Japanese quail eggs during incubation positively influenced some behavioral features. These findings suggest that either of these lighting systems could be utilized to increase broiler chicken hatchability and chick quality. Using various types of lighting in commercial hatcheries can enhance efficiency by increasing hatchability and the quality of the chicks hatched (Archer 2018).

Less active chickens may grow faster, but the proactive phenotypic may be more physically active, with differential effects on postembryonic development and broiler welfare (Drozdová et al 2021). In agreement, Senaratna et al (2016) revealed that raising broilers under red light conditions increased weight gain and bird preference compared to other light colors. On the other hand, Seo et al (2016) reported that rearing broilers under shorter wavelength LEDs such as pure blue and bright blue can improve their growth and immune response at a later stage of production. They also found that an increase in the immune response can reduce disease risk and treatment expenses, resulting in improved survival rates and lower production costs, which support profitability. Furthermore, fear and stress were reduced when broilers were reared under blue LED light (Mohamed et al 2014).

Li et al (2019) conducted a study about a lighting preference test system to explore the layer preferences for four light-emitting diode colors: white, red, green, and blue. They discovered that layers preferred to stay in blue light when the light was turned on and in white light 4 hours before it was turned off. Consequently, pullets preferred blue light more than red light.

However, Campo et al (2007) and Hesham et al (2018) observed that abnormal behavior (aggression, fighting, and feather pecking) was significantly higher in birds raised under red light than in light of other colors due to the increased activity of birds under red light. Su et al (2021) also found that laying ducks reared under the red light showed more activity and less resting behavior than those reared under the blue light, and higher egg production performance than those reared under the white and blue light. On the other hand,
Wei et al (2020) revealed that carefully staged spectrum management using LED lights can improve immunological performance, bone growth, and production performance of caged layer chicks during their brooding and rearing phases. The blue-green light enhanced serum Ig and serum glucose concentrations in layer chickens during phase 1 (0-13 weeks of age). At phase 2 (14-20 weeks of age), the yellow-orange light raised bone mineral density concentrations, encouraged sexual organ (oviduct and ovary) growth, advanced the age of sexual maturation, and improved layer chicken production uniformity. In addition, light colors influence layer pullets' drinking preferences. The pullets preferred to drink under blue light for the first six hours of the daylight, and under white light for the last hours. Therefore, most pullets preferred to drink under blue and white lights compared to other light colors ( $\mathrm{Li}$ et al 2020). This preference could be attributed to light wavelength differences. The blue and green colors have shorter wavelengths ( $480 \mathrm{~nm}$ and $520 \mathrm{~nm}$, respectively) than the red and yellow colors ( $700 \mathrm{~nm}$ and 580 $\mathrm{nm}$, respectively), while the white color has a wavelength between $400-700 \mathrm{~nm}$.

These findings verify layer preferences for light colors, providing insights for managing LED colors to fulfill pullet needs ( $\mathrm{Li}$ et al 2019) and confirming that layer color preferences differ depending on the development stage. Furthermore, combined lighting colors can have a large future impact among researchers and breeders as a novel technique to enhance broiler and layer productive performance. Oke et al (2021b) stated that using green light for up to 28 days in combination with blue light increased broiler chicken growth, and manipulating light colors can improve chicken welfare and performance. Pan et al (2014) revealed that spectral composition has a significant impact on bird growth and physiology. According to the findings of their study, green-blue dual light has two side effects on chick body mass, depending on the green to blue ratio. When compared to monochromatic green or blue spectra-treated chicks, green-blue dual light with depleted and medium blue components decreased body mass while enriched blue component promoted body mass. Soliman and El-Sabrout (2020) concluded that more than $50 \%$ of the poultry research in this view showed that blue $(450 \mathrm{~nm})$ and green light (550 $\mathrm{nm}$ ) had a positive impact on body weight (>3\%); while red light $(700 \mathrm{~nm})$ increased activity and aggressive behavior in birds (>30\%) with negatively influencing body weight. Therefore, it is recommended that red lighting be provided in the regions around the feeders and drinkers, and blue or green lighting be provided in other areas of the poultry houses for relaxing and other daily activities.

\subsection{Light intensity (brightness)}

Light intensity (also called illuminance or density), as one of the primary components of light that affects lighting quantity, can also influence birds' behavior and productivity (Patel et al 2016). It considerably influences birds' behavioral activities (walking, foraging, drinking, among others). In general, brighter light encourages more activity, whereas 
lower intensities are beneficial at controlling aggressive behaviors that can lead to cannibalism. Aldridge et al (2021) studied the usage of two common poultry-specific LEDs with varying light warmth $(2,700 \mathrm{~K}$ and $5,000 \mathrm{~K})$. They concluded that birds in the cool-warm treatment had a strong preference for warm light during the first and last hours of the 16-hour light period. Different light temperatures could enhance the market body weight of broiler chickens. Lighting patterns for birds are primarily used to stimulate and manage feed intake. Working on quails, Maty et al (2021) reported that exposing birds to high light intensity ( 25 lux) resulted in a significant improvement in feed conversion ratio and some constituent blood concentrations, such as PCV and hemoglobin concentrations, as well as some positive effects on bird's semen quality such as sperm live percentage. High light intensities (20-40 lux or 2-4 foot-candles) have been related to increased feed intake, rapid growth, and may positively affect the reproductive performance of birds; while low light intensities (3-5 lux) have been related to less movement and standing, as well as lower rates of fighting, feather pecking, and cannibalism (Buyse et al 1996). Therefore, it is recommended that broiler chicks be raised with a light intensity of at least 20 lux in the areas around the feeders and drinkers. Light intensity should be reduced in other areas for resting and other daily activities (Raccoursier et al 2019). Using this light intensity strategy, birds can choose between different area intensities based on their preferences and current behavior, improving their welfare. Breeders often employ modern electronic systems to enhance light intensity for short periods during grow-out to increase exercise and prevent skeletal and metabolic diseases.

\subsection{Lighting duration (photoperiod)}

The duration of light exposure substantially impacts the bird's growth, maturation, and reproduction. It affects poultry meat and egg production by activating growth and sexual hormones. The lighting duration is mainly determined by the age of the birds involved and the type of housing used (Patel et al 2016). In general, it is recommended to provide broiler chicks with 24 hours of light per day, gradually decreasing after the first days of the chick's life to ensure newly placed chicks locate feed and water and maximize intake by encouraging chick activity. During the production period, hens require at least 12 hours of daylight per day to lay regular eggs, and 14 to 16 hours of sunlight per day will keep them performing at their peak. Moreover, darkness is just as critical to bird's growth and health as light. Short photoperiods early in life are thought to restrict feed intake and impede growth. Researchers and breeders have investigated many light-duration strategies, and almost all of them have been shown to improve broiler growth and welfare (Patel et al 2016). However, the current review suggests that a minimum continuous dark period of 4-8 hours should be provided for birds based on their developing stages.
3. Density strategies to improve poultry behavior, health, and production

\subsection{Importance of stocking density}

Stocking density (SD) or crowding is one of the most prominent issues in the poultry industry and largely depends upon birds' behavior, welfare, health, and productivity (Figure 3). Stocking density can be defined as the amount of space available per bird. Moreover, it can also be defined as the number of birds reared in exact space $\left(\mathrm{m}^{2}\right)$ or broiler meat per unit area (Berg and Yngvesson 2012). Consumer awareness of avian welfare has grown in recent years, and as a result, consideration for higher-quality meat production has increased. People's perception of crowding causes serious welfare concerns to stimulate scientists to reduce SD and farmers to give their birds more space. Stocking density is considered the most influential factor that affects birds' welfare, physical activity, and production quality (Gomes et al 2014; Zhao et al 2021). Despite having several works on SD in poultry birds from the last few years (Table 2), conflict still exists between the bird's welfare interest that is more inclined towards more space given to the birds and the commercial producer who is willing to put more birds in the same space. Therefore, there is a diverse opinion about measuring the space and how much the bird needs (Dawkins 2018; Zhao et al 2021).

\subsection{Stocking density effects on bird's behavior}

Many studies reported a significant association between SD and the behavior of broiler chickens (Dawkins et al 2004; Abudabos et al 2013; Toghyani et al 2016; Zhao et al 2021). A study on broilers revealed a negative correlation between high SD and eating or drinking frequency (Beilmann et al 2005). When birds were reared under 1.7 and $14 \mathrm{~kg} / \mathrm{m}^{2}$, walking and sitting behaviors were more pronounced under the lower SD, and birds were involved less time in dozing and sleeping (Andrews et al 1997). Another study assessed broiler behaviors under different SDs (30-32, 36-38, and $42-44 \mathrm{~kg} / \mathrm{m}^{2}$ at $1700 \mathrm{~g}$ market age), revealed less locomotion and higher incidence of resting and standing in birds under higher SD (Son 2013). Furthermore, less feeding and drinking behavior were observed in commercial broilers when reared under the SDs from 27 to $39 \mathrm{~kg} / \mathrm{m}^{2}$ (Li et al 2020). Similarly, lower feeding and drinking behaviors were reported when birds were reared under 34 vs. $40 \mathrm{~kg} / \mathrm{m}^{2}$ SDs at $2000 \mathrm{~g}$ market weight (Hall 2001). Another study reported that SD did not affect broiler chickens' drinking and eating behaviors (lyasere et al 2012). Contrarily, Simitzis et al (2012) reported a higher frequency of feeding behavior and feeder visit in broiler chickens under $12.6 \mathrm{~kg} / \mathrm{m}^{2} \mathrm{SD}$ than the recommended range of $27 \mathrm{~kg} / \mathrm{m}^{2}$. However, Li et al (2020) found a similar trend of feeding and drinking behaviors when broiler chickens reared under $27-39 \mathrm{~kg} / \mathrm{m}^{2}$.

A study regarding Thai crossbred chickens (Luang Hang Khao) revealed that stocking did not influence feather pecking frequency on different body parts except wings, bird 
reared under 12 birds $/ \mathrm{m}^{2}$ showed the highest frequency of wing pecking. The intense feather pulling was found in birds under 8 birds $/ \mathrm{m}^{2}$ (Huo and Na-Lampang 2016). This aggressive behavior of the birds could be due to their inherited genetic potential as Thai crossbred chickens have the traits of fighting; therefore, when the birds were reared under intensity grouping, they expressed a higher frequency of aggressive behavior and cannibalism (Huo and $\mathrm{Na}$ Lampang 2016). In the study of Muscovy ducks, exploratory behaviors were more pronounced in birds reared under 9 birds $/ \mathrm{m}^{2}$ (Baeza et al 2003).

Table 2 The main results regarding density aspects on improving poultry behavior, health, and production.

\begin{tabular}{|c|c|c|c|c|}
\hline $\begin{array}{l}\text { Effect-causing } \\
\text { agents }\end{array}$ & Evaluated variables & Species & Main results & References \\
\hline \multirow[t]{2}{*}{$\begin{array}{l}\text { Housing system and } \\
\text { stocking density }\end{array}$} & $\begin{array}{l}\text { Performance, carcass } \\
\text { traits, blood indices, } \\
\text { and meat quality }\end{array}$ & $\begin{array}{l}\text { French } \\
\text { pekin } \\
\text { ducks }\end{array}$ & $\begin{array}{l}\text { The meat contents of triglycerides and total cholesterol decreased } \\
\text { in higher stocking density. Serum antioxidant indices were reduced } \\
\text { in the plastic slatted floors. Housing on plastic slatted floors } \\
\text { improved growth performance, carcass traits, meat cholesterol, and } \\
\text { antioxidant status }\end{array}$ & $\begin{array}{l}\text { Abo } \\
\text { Ghanima } \\
\text { et al } \\
(2020)\end{array}$ \\
\hline & Welfare & $\begin{array}{l}\text { Broiler } \\
\text { chickens }\end{array}$ & $\begin{array}{l}\text { Differences among producers in the environment that companies } \\
\text { provide for chickens have more impact on welfare than has stocking } \\
\text { density itself. }\end{array}$ & $\begin{array}{l}\text { Dawkins et } \\
\text { al (2004) }\end{array}$ \\
\hline \multirow[t]{7}{*}{ Stocking density } & $\begin{array}{l}\text { Performance and } \\
\text { Immunity }\end{array}$ & $\begin{array}{l}\text { Chicks } \\
\text { Ross } 308 \\
\text { Broiler } \\
\text { Chickens }\end{array}$ & $\begin{array}{l}\text { Feed conversion ratio, body weight gain, and feed intake were } \\
\text { improved significantly in } 12 \text { chicks' density compared to } 18 \text { chicks. } \\
\text { Stocking density had no significant effect on mortality, as well as the } \\
\text { relative weights of the spleen, bursa of Fabricius, abdominal fat, } \\
\text { thigh, and breast }\end{array}$ & $\begin{array}{l}\text { Astaneh et } \\
\text { al (2018) }\end{array}$ \\
\hline & $\begin{array}{l}\text { Welfare, growth } \\
\text { performance and } \\
\text { carcass quality }\end{array}$ & $\begin{array}{l}\text { Muscovy } \\
\text { ducks }\end{array}$ & $\begin{array}{l}\text { Starter ducks' final body weight and weight gain were reduced } \\
\text { significantly as stocking density increased from } 17 \text { to } 21 \text { birds } / \mathrm{m}^{2} \text {. } \\
\text { The stocking density had no significant effects on feed/gain and } \\
\text { mortality }\end{array}$ & $\begin{array}{l}\text { Baeza et al } \\
\text { (2003) }\end{array}$ \\
\hline & $\begin{array}{l}\text { Performance, relative } \\
\text { carcass yield, gut } \\
\text { microflora, and stress } \\
\text { markers }\end{array}$ & $\begin{array}{l}\text { Broiler } \\
\text { chickens }\end{array}$ & $\begin{array}{l}\text { High stocking density of } 20 \text { birds } / \mathrm{m}^{2} \text { negatively affected the } \\
\text { performance and intestinal } \\
\text { Lactobacillipopulationofbroilerscomparedtothelowstockingdensityof } \\
10 \text { birds } / \mathrm{m}^{2}\end{array}$ & $\begin{array}{l}\text { Cengiz et } \\
\text { al (2015) }\end{array}$ \\
\hline & $\begin{array}{l}\text { Performance, body } \\
\text { conformation, and } \\
\text { welfare }\end{array}$ & $\begin{array}{l}\text { Broiler } \\
\text { chickens }\end{array}$ & $\begin{array}{l}\text { The high stocking density affects the parameters regarding } \\
\text { conformation, performance and welfare of male broilers }\end{array}$ & $\begin{array}{l}\text { Weimer et } \\
\text { al (2020) }\end{array}$ \\
\hline & $\begin{array}{l}\text { Musculo skeletal } \\
\text { development of } \\
\text { pullets }\end{array}$ & Pullets & $\begin{array}{l}\text { Overall, stocking density ( } 247 \mathrm{~cm}^{2} / \mathrm{bird}, 270 \mathrm{~cm}^{2} / \mathrm{bird}, 299 \mathrm{~cm}^{2} / \mathrm{bird} \text {, } \\
\text { and } 335 \mathrm{~cm}^{2} / \text { bird) during rearing had little impact on the musculo } \\
\text { skeletal growth of pullets }\end{array}$ & $\begin{array}{l}\text { Fawcett et } \\
\text { al (2020) }\end{array}$ \\
\hline & Welfare indices & $\begin{array}{l}\text { Broiler } \\
\text { chickens }\end{array}$ & $\begin{array}{l}\text { Short-term high stocking density markedly increased broilers' stress } \\
\text { and jeopardize their welfare }\end{array}$ & $\begin{array}{l}\text { Abudabos } \\
\text { et al } \\
(2013)\end{array}$ \\
\hline & $\begin{array}{l}\text { Behavior and } \\
\text { performance }\end{array}$ & $\begin{array}{l}\text { Broiler } \\
\text { chickens }\end{array}$ & $\begin{array}{l}\text { The stocking density negatively correlated to the welfare behavior } \\
\text { indicators and performance }\end{array}$ & $\begin{array}{l}\text { Abo } \\
\text { Alqassem } \\
\text { et al } \\
(2018)\end{array}$ \\
\hline $\begin{array}{l}\text { Air velocity and } \\
\text { stocking density }\end{array}$ & $\begin{array}{l}\text { Eating and drinking } \\
\text { behavior and } \\
\text { performance }\end{array}$ & $\begin{array}{l}\text { Broiler } \\
\text { chickens }\end{array}$ & $\begin{array}{l}\text { Birds in pens with higher air velocity had better feeding behavior, } \\
\text { weight gain, and feed efficiency. Increasing the stocking density } \\
\text { reduced feed intake and weight gain but enhanced the feeding } \\
\text { behavior of the birds }\end{array}$ & $\begin{array}{l}\text { Beilmann } \\
\text { et al } \\
(2005)\end{array}$ \\
\hline $\begin{array}{l}\text { Temperature and } \\
\text { stocking density }\end{array}$ & $\begin{array}{l}\text { Acute phase proteins, } \\
\text { heat shock proteins, } \\
\text { circulating } \\
\text { corticosterone and } \\
\text { performance }\end{array}$ & $\begin{array}{l}\text { Broiler } \\
\text { chickens }\end{array}$ & $\begin{array}{l}\text { High temperature and high stocking density was physiologically } \\
\text { stressful to broiler chickens, as indicated by corticosterone, } \alpha 1 \text {-acid } \\
\text { glycoprotein, ceruloplasmin, ovotransferrin and heat shock protein } \\
\text { HSP 70, but not detrimental to growth performance and } \\
\text { survivability }\end{array}$ & $\begin{array}{l}\text { Najafi et al } \\
\text { (2015) }\end{array}$ \\
\hline $\begin{array}{l}\text { Cage height and } \\
\text { stocking density }\end{array}$ & $\begin{array}{l}\text { Behavior and } \\
\text { response to stimuli }\end{array}$ & $\begin{array}{l}\text { Laying } \\
\text { hens }\end{array}$ & $\begin{array}{l}\text { The changes in horizontal and vertical space over the ranges we } \\
\text { studied had little effect on behavior other than feeding behavior. }\end{array}$ & $\begin{array}{c}\text { Albentosa } \\
\text { et al } \\
(2007)\end{array}$ \\
\hline $\begin{array}{l}\text { Perch availability } \\
\text { and stocking of } \\
\text { density }\end{array}$ & Immune status & $\begin{array}{l}\text { Broiler } \\
\text { chickens }\end{array}$ & $\begin{array}{l}\text { As density increased, bursa weight and bursa/body weight ratios } \\
\text { significantly decreased. The addition of perches to the pens also } \\
\text { significantly decreased the bursa weights and bursa/body weight } \\
\text { index }\end{array}$ & $\begin{array}{l}\text { Heckert et } \\
\text { al (2002) }\end{array}$ \\
\hline
\end{tabular}


Lower incidence of feeding and drinking were observed in laying hens when reared at high SD (Albentosa et al 2007). In a study of Leghorn pullets, SD influenced feeding and standing behaviors, and these behaviors were more pronounced when birds were reared at a density of 23 birds $/ \mathrm{m}^{2}$ (Hofmann et al 2021).

\subsection{Stocking density impacts on bird's health and welfare}

Higher SD is considered the main stressor in poultry and is generally associated with endocrinological alterations and demotes the bird's welfare. A study assessed the tonic immobility of commercial broilers under different SDs (6-56 $\mathrm{kg} / \mathrm{m}^{2}$ considering $2600 \mathrm{~g}$ market weight) and revealed higher fearfulness in birds reared under higher SD. During the growing phase of broiler chickens, antibody titters against New Castle Disease and Infectious Bronchitis were raised when birds reared under low SD (Abudabos et al 2013). Other studies reported a higher incidence of footpad dermatitis in broiler chickens with increasing SD (455-622 cm/bird) (Sorensen et al 2000; Dozier et al 2006). A study of male broiler chickens revealed high lesions score when reared at 40 and $45 \mathrm{~kg} / \mathrm{m}^{2}$ SD (Dozier et al 2005). Another study reported reduced lymphoid organ weight of broiler chickens when reared at higher SD (Ravindran et al 2006). Reduced immunity in broiler chicken was also reported by another scientist when stocked at high SD (Heckert et al 2002; Palizdar et al 2017).

Higher SD also impacts biochemical response, as the studies reported higher heterophile, and stress hormones when in commercial broilers when reared under higher SD (Najafi et al 2015; Astaneh et al 2018). When Arbor Acres and Ross 308 broiler chickens were reared with increased SD, it influenced blood biochemical profile, and ALT, AST, urea, and creatine were linearly increased (Nasr et al 2021). Other studies reported reduced total protein, albumin, globulin, ALT, AST (Abudabos et al 2013), cholesterol, and HDL (Sahin and Kucukm 2001) in broiler chickens reared at high SD. Increased $\mathrm{H} / \mathrm{L}$ ratio was also noted in broiler chickens when reared under high SD (Cengiz et al 2015). In a study of Ross 308 male broilers, decreased $\mathrm{H} / \mathrm{L}$ ratio was also reported due to overcrowding stress (Chegini et al 2018). However, another study did not find any difference in lymphoid organ weight, blood glucose level, and passive immunity in broiler chickens when reared at $120,90,60$, and $30 \mathrm{bird} / \mathrm{m}^{2}$ (Qaid et al 2016).

When Muscovy ducks were reared under $9 \mathrm{birds} / \mathrm{m}^{2}$, it showed better welfare aspects and overall performance (Baeza et al 2003). Another study on Pekin duck revealed that the incidence of footpad dermatitis did not influence by increasing SD (Xie et al 2014). In a study of Japanese quail, higher SD significantly reduced the immune response (Erisir and Erisir 2002). When reared at high SD, increased spleen weight was also reported in Japanese quail (Mahrose et al 2019).

Working on white leghorn hens, Hofmann et al (2021) revealed that the number of blood lymphocytes was lower in both the rearing and laying phase at high SD and severe feather pecking at the tail, footpad, and comb lesions were also reported when the bird stocked at $23 \mathrm{birds} / \mathrm{m}^{2}$.

\subsection{Stocking density effects on productivity of the bird}

Stocking density largely influences the total performance of poultry birds such as broiler chickens, and several studies reported adverse effects of higher SD on bird's growth and productivity (Petek et al 2014; Chegini et al 2018). Increasing the SD of birds slowed development, growth, and increased oxidative stress (Jobe et al 2019). High SD $\left(20\right.$ birds $\left./ \mathrm{m}^{2}\right)$ can adversely affect broiler chickens' growth performance and market weight (Cengiz et al 2015). Poor growth performance and feed efficiency were also reported in Arbor Acres chickens when stocked at $45 \mathrm{~kg} / \mathrm{m}^{2}$ (Li et al 2019). Similarly, another study reported negative effects on feed consumption and weight gain of commercial male broiler chickens when reared under 35 to $45 \mathrm{~kg} / \mathrm{m}^{2}$ for 49 days (Dozier et al 2005). Depression in feed intake was also reported when high SD was provided to fast-growing broilers and reported this decline because of limited access to feeders and drinkers (Feddes et al 2002). Moreover, a poor feed conversion ratio was reported in broiler chicken when reared at 16 birds $/ \mathrm{m}^{2}$ (Houshmand et al 2012). A higher mortality rate $(5 \%)$ was also noted in broiler chickens when reared at $29 \mathrm{~kg} / \mathrm{m}^{2}$. Furthermore, most extended bodies and keel length and narrower breast and pelvic were also reported at $37 \mathrm{~kg} / \mathrm{m}^{2}$ (Weimer et al 2020).

Improved carcass weight and meat yield were noted when Arbor Acres broilers were reared at $15 \mathrm{bird} / \mathrm{m}^{2}$ (Abo Alqassem et al 2018). Broiler chickens reared at high SD (more than $15 \mathrm{bird} / \mathrm{m}^{2}$ ) significantly reduce the carcass quality, especially thigh, breast yield, and lower breast fillet (Abo Ghanima et al 2020). On the other hand, contradictory studies reported that broiler chickens reared at different SD did not exhibit any significant difference in growth parameters and carcass traits (Nogueira et al 2013; Kryeziu et al 2018; Obeidat et al 2019). In agreement, Avian 48 and Ross 308 broilers, when reared at 40 and $30 \mathrm{~kg}$ body weight $/ \mathrm{m}^{2}$, did not show any difference in growth performance (Ligaraba et al 2016; Palizdar et al 2017). Furthermore, increasing SD did not influence mortality rate in a study of fast-growing broiler chickens (Thomas et al 2004; Simsek et al 2011) and carcass traits (Zuowei et al 2011). Similarly, meat quality traits of different broiler strains did not influence SD when reared between 10 and 16 birds $/ \mathrm{m}^{2}$ (Moreira et al 2004). Working on laying chickens, SD influenced musculoskeletal traits, especially the amount of cartilage on keel bone and leg muscle weight in leghorn pullets. Birds reared at low SD (247 $\mathrm{cm}^{2} /$ bird) had the heaviest leg muscles and the lowest cartilage amount on keel bone (Fawcett et al 2020).

In a study of White Pekin ducks, the increasing SD did not influence the birds' mortality during the day of hatch to forty-two days of age. However, increasing SD negatively affects growth performance (Xie et al 2014). Another study on Pekin ducks reported that birds reared under $8 \mathrm{birds} / \mathrm{m}^{2}$ for four weeks and 4 birds $/ \mathrm{m}^{2}$ until market age revealed the highest weight gain and optimum market age. Moreover, 
breast and thigh yield dropped in 8 birds $/ \mathrm{m}^{2}$ reared birds (Osman 1993). Similarly, in European countries, the general trend for SD is 6-8 birds $/ \mathrm{m}^{2}$ for Pekin duck (Rodenburg et al 2005).

In general, higher SD reduces bird performance, especially feed conversion ratio, weight gain, and increases mortality. Moreover, the incidence of footpad lesions increases in broiler chickens with increasing SD. Higher SD has been associated with major stress in poultry birds resulted in higher pecking in laying hens and aggression in broiler chickens. From the previous literature, the recommended SD for laying chickens raised in a non-cage system throughout the production stage is $12 \mathrm{birds} / \mathrm{m} 2\left(30 \mathrm{~kg} / \mathrm{m}^{2}\right)$. The optimal SD for caged layers is $370 \mathrm{~cm}^{2} /$ bird throughout the rearing stage and $550 \mathrm{~cm}^{2} /$ bird during production. Broiler chickens reared at a medium SD (18 birds $/ \mathrm{m}^{2}$ or $36 \mathrm{~kg} / \mathrm{m}^{2}$ ) had better productive performance and welfare than those raised at high $\left(20 \mathrm{birds} / \mathrm{m}^{2}\right.$ ) or low $\left(14 \mathrm{birds} / \mathrm{m}^{2}\right)$ densities, according to Nasr et al (2021). As a result, medium-density was the most cost-effective option. The recommended SD for layer and broiler breeder chickens is $30 \mathrm{~kg} / \mathrm{m}^{2}$. Japanese quail, ducks, and turkey can also better be stocked at SDs of 200 $\mathrm{cm}^{2} /$ bird, $30 \mathrm{~kg} / \mathrm{m}^{2}$, and $0.3715 \mathrm{~m}^{2} /$ bird, respectively.

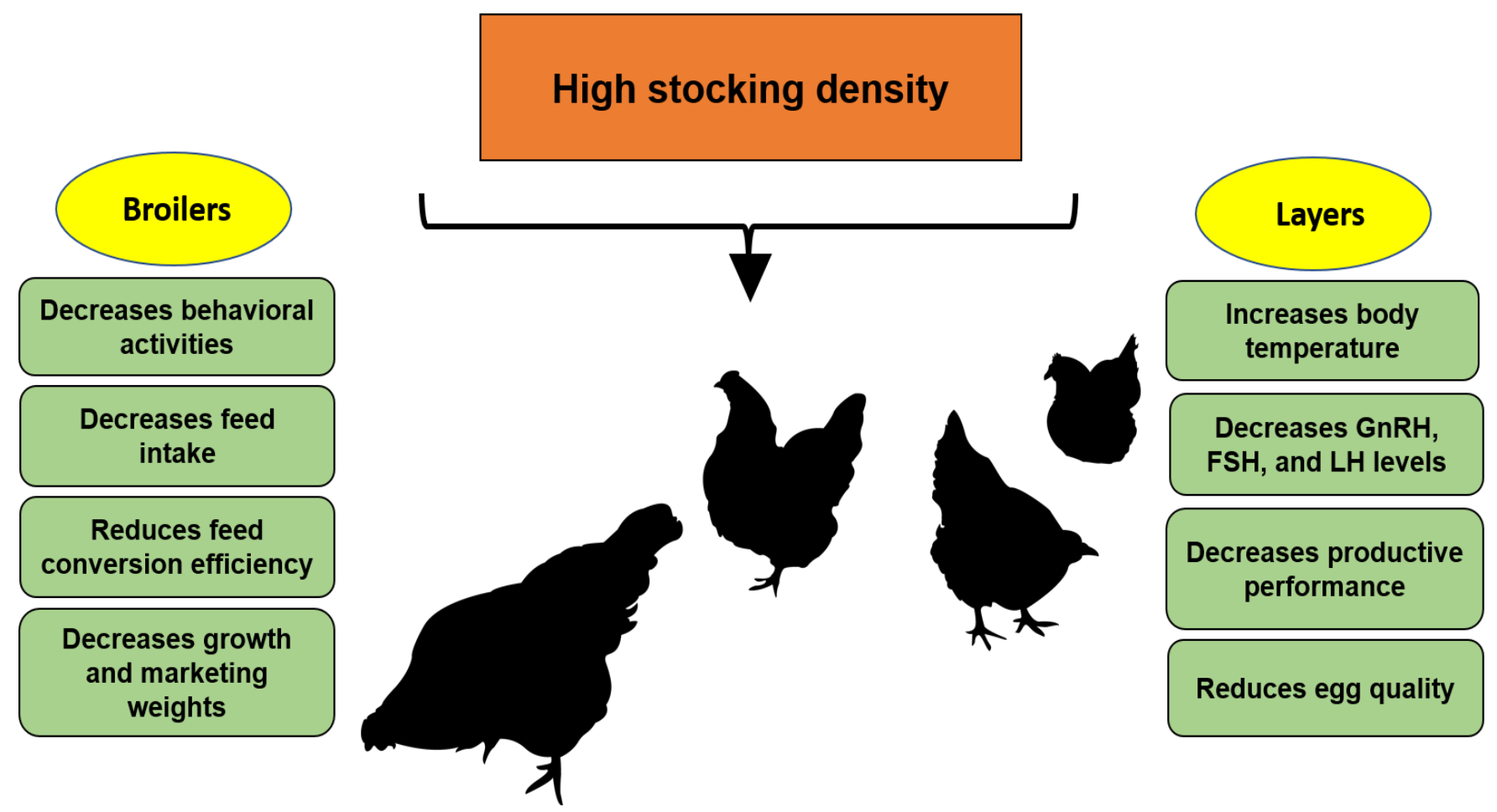

Figure $\mathbf{3}$ Potential impacts caused by high stocking density on birds.

4. Dietary strategies to improve poultry behavior, health, and production

The main results regarding dietary aspects on improving poultry behavior, health, and production showed in Table 3.

\subsection{Effect of dietary strategies on bird's health and welfare}

The current commercial chicken is the consequence of years of intensive genetic selection for growth and egg production. Intending to express the genetic potential of these high-yielding birds, balanced nutrition is mandatory and considered a contributing factor in the economics of poultry enterprise. The primary concern for poultry nutritionists is to optimize the diet that can improve birds' health. Therefore, poultry health and ultimately welfare aspects are considered significant criteria for developing dietary strategies in poultry (Whitehead 2002; Zuidhof et al 2015). Protein modifications (amino acids) and energy contents can alter productivity, especially growth, morphometrics, intestinal health, egg production, and egg quality traits (Husveth et al 2015). Imbalanced minerals and vitamin or their deficiency may cause welfare problems, e.g., lesions. Similarly, the ideal dietary strategy can reduce heat stress in poultry birds. Furthermore, the genetic disorders in broiler chickens (cardio muscular and skeletal deformities) can be reduced by a dietary modification that decreases the fast muscular growth (Reiter and Bessei 2000; Whitehead 2002).

The principal aim of formulating broiler diets is to achieve maximum body weight at all ages; however, poultry nutritionists continuously improve the feed strategies to formulate the diet of meat-type birds according to the age requirement. Manipulation of broiler diet to slow down the growth during earlier age could be advantageous as bones are more suspectable to lesions that affect broiler health and welfare (De Jong et al 2012). However, the later stage of broiler life requires a higher nutrient diet that can allow the birds to achieve compensatory growth and develop the ideal 
market age. This occurs because modern broiler genotypes are less suspectable to footpad dermatitis (FPD) and have fewer incidences of skeletal deformities (Meluzzi et al 2008; Skrbic et al 2015). Another dietary strategy to improve the incidence of tibial dyschondroplasia (TD) in broiler chickens is fasting. Providing a fasting period of almost 8 hours a day could be beneficial for birds to utilize all the nutrients effectively and enhance walking ability that ultimately improves birds' health. A study on broiler chickens revealed that the provision of meals 2-4 times a day enhances walking ability with improved gait and reduces FPD incidence (Su et al 1999; Whitehead 2002).

Table 3 The main results regarding dietary aspects on improving poultry behavior, health, and production.

\begin{tabular}{|c|c|c|c|c|}
\hline Effect-causing agents & Evaluated variables & Species & Main results & References \\
\hline $\begin{array}{l}\text { Unpredictable feed } \\
\text { delivery }\end{array}$ & $\begin{array}{l}\text { The development of } \\
\text { fault bars }\end{array}$ & $\begin{array}{l}\text { Gallus } \\
\text { gallus } \\
\text { domesticus }\end{array}$ & $\begin{array}{l}\text { Feather traits, including fault bars and feather growth, can be used as } \\
\text { indicators of negative welfare in chickens }\end{array}$ & $\begin{array}{l}\text { Arrazola and } \\
\text { Torrey } \\
\text { (2019) }\end{array}$ \\
\hline $\begin{array}{l}\text { Dietary insoluble } \\
\text { fiber }\end{array}$ & Behavior and hunger & $\begin{array}{l}\text { Broiler } \\
\text { breeders }\end{array}$ & $\begin{array}{l}\text { High-fiber diets can alleviate the feeling of hunger currently } \\
\text { experienced by broiler breeders, and a high ratio of insoluble fiber } \\
\text { may improve the well-being of the birds }\end{array}$ & $\begin{array}{l}\text { Nielsen et al } \\
\text { (2011) }\end{array}$ \\
\hline Feeding management & $\begin{array}{l}\text { Body weight and } \\
\text { carcass uniformity }\end{array}$ & Pullets & $\begin{array}{l}\text { Birds on the high fiber treatment consumed more feed and had the } \\
\text { highest feed conversion ratio. Scatter feeding increased flock } \\
\text { uniformity }\end{array}$ & $\begin{array}{l}\text { Zuidhof et al } \\
\qquad \text { (2015) }\end{array}$ \\
\hline Protein source & $\begin{array}{l}\text { Development of } \\
\text { footpad dermatitis }\end{array}$ & $\begin{array}{l}\text { Broiler } \\
\text { chickens }\end{array}$ & $\begin{array}{l}\text { Mixed protein source diet increased body weight and improved } \\
\text { footpad dermatitis significantly. The incidence and severity of footpad } \\
\text { dermatitis were highest in birds reared on wood flooring }\end{array}$ & $\begin{array}{l}\text { Cengiz et al } \\
\qquad(2013)\end{array}$ \\
\hline \multirow[t]{2}{*}{$\begin{array}{l}\text { Dietary probiotic } \\
\text { supplementation }\end{array}$} & $\begin{array}{l}\text { Performance, relative } \\
\text { carcass yield, gut } \\
\text { microflora, and stress } \\
\text { markers }\end{array}$ & $\begin{array}{l}\text { Broiler } \\
\text { chickens }\end{array}$ & $\begin{array}{l}\text { Dietary probiotic supplementation did not affect the relative carcass } \\
\text { yield, weight of lymphoid organs, serum malondialdehyde, } \\
\text { corticosterone, nitric oxide, and plasma heterophil: lymphocyte, stress } \\
\text { indicators, total aerobes, Salmonella, and Lactobacilli in the intestines } \\
\text { of the broilers }\end{array}$ & $\begin{array}{l}\text { Cengiz et al } \\
\qquad(2015)\end{array}$ \\
\hline & $\begin{array}{l}\text { Growth, carcass traits, } \\
\text { and lymphoid organs }\end{array}$ & $\begin{array}{l}\text { Japanese } \\
\text { quail }\end{array}$ & $\begin{array}{l}\text { Birds fed a diet supplemented with probiotics (Lactobacillus) at } 0.02 \\
\mathrm{~g} / \mathrm{kg} \text { showed the highest spleen weight significantly. Probiotic } \\
\text { supplementation diminished the stressful effect of crowding }\end{array}$ & $\begin{array}{l}\text { Mahrose et } \\
\text { al (2019) }\end{array}$ \\
\hline $\begin{array}{l}\text { Propolis } \\
\text { supplementation }\end{array}$ & $\begin{array}{l}\text { Heat stress, growth } \\
\text { performance, } \\
\text { immunity, and stress } \\
\text { indicators }\end{array}$ & $\begin{array}{l}\text { Broiler } \\
\text { chickens }\end{array}$ & $\begin{array}{l}\text { Dietary use of propolis as a feed supplement can reduce some of the } \\
\text { detrimental effects of heat stress and high stocking density in broilers }\end{array}$ & $\begin{array}{l}\text { Chegini et al } \\
\qquad(2018)\end{array}$ \\
\hline \multirow[t]{2}{*}{$\begin{array}{l}\text { Different feeding } \\
\text { times }\end{array}$} & Performance & $\begin{array}{l}\text { Broiler } \\
\text { chickens }\end{array}$ & $\begin{array}{l}\text { It is possible to change conventional feeding management's ( } \mathrm{T} 1= \\
\text { feeding at 6:30 a.m.; T2 = 50\% feeding at 6:30 a.m. and } 50 \% \text { at 3:30 } \\
\text { p.m.) by the dual feeding system ( } \mathrm{T} 3=\text { feeding at 11:00 a.m.; and } \mathrm{T} 4= \\
\text { feeding at 3:30 p.m.) }\end{array}$ & $\begin{array}{l}\text { De Avila et al } \\
\text { (2003) }\end{array}$ \\
\hline & $\begin{array}{l}\text { Shell quality and } \\
\text { oviposition time }\end{array}$ & Laying hens & $\begin{array}{l}\text { Mean eggshell thickness was increased by } 3-5 \mu \mathrm{m} \text { per } \mathrm{h} \text { delay in } \\
\text { feeding time when hens were housed in individual cages but was not } \\
\text { when birds were housed on litter floors. Mean oviposition time was } \\
\text { delayed relative to lights on by } 5 \text { min per h delay in feeding time }\end{array}$ & $\begin{array}{l}\text { Backhouse } \\
\text { and Gous } \\
\text { (2005) }\end{array}$ \\
\hline $\begin{array}{l}\text { Timing and durations } \\
\text { of feed restriction }\end{array}$ & $\begin{array}{l}\text { Reproductive } \\
\text { characteristic }\end{array}$ & $\begin{array}{l}\text { Broiler } \\
\text { breeder } \\
\text { females }\end{array}$ & $\begin{array}{l}\text { The birds of feed restricted had higher proportional weights of the } \\
\text { ovary and oviductal the age of sexual maturity. The } \mathrm{CL} \mathrm{HRH-I} \mathrm{levels} \mathrm{and} \\
\text { gonadotrophin contents in the pituitary followed that of growth in } \\
\text { response to feeding levels and timing of feeding, related to the timing } \\
\text { of the onset of lay }\end{array}$ & $\begin{array}{l}\text { De Jong et al } \\
\qquad(2002 b)\end{array}$ \\
\hline $\begin{array}{l}\text { Vegetable and animal } \\
\text { protein diet }\end{array}$ & $\begin{array}{l}\text { Growth, excreta } \\
\text { quality, nutrient } \\
\text { digestibility, and bone } \\
\text { development }\end{array}$ & $\begin{array}{l}\text { Broiler } \\
\text { chickens }\end{array}$ & $\begin{array}{l}\text { In general, parameter responses indicated that the animal protein diet } \\
\text { was superior to the vegetable protein diet }\end{array}$ & $\begin{array}{l}\text { Hossain et al } \\
\qquad(2013)\end{array}$ \\
\hline $\begin{array}{l}\text { Whole wheat } \\
\text { supplement }\end{array}$ & $\begin{array}{l}\text { Growth performance } \\
\text { and intestinal } \\
\text { function }\end{array}$ & $\begin{array}{l}\text { Broiler } \\
\text { chickens }\end{array}$ & $\begin{array}{l}\text { Compared to the control group, wheat seed feeding increased gizzard } \\
\text { weight, presented higher trypsin, } \alpha \text {-amylase, and lipase activities were } \\
\text { detected in the jejunal digesta when the diets contained whole wheat }\end{array}$ & $\begin{array}{l}\text { Husveth et al } \\
\text { (2015) }\end{array}$ \\
\hline \multirow[t]{3}{*}{ Feeding frequency } & $\begin{array}{l}\text { Indicators of hunger } \\
\text { and frustration }\end{array}$ & $\begin{array}{l}\text { Broiler } \\
\text { chickens }\end{array}$ & $\begin{array}{l}\text { Scattered feeding, feeding twice a day and a combination of these two } \\
\text { feeding strategies do not significantly improve broiler breeder welfare } \\
\text { during rearing as indicators of hunger have not changed }\end{array}$ & $\begin{array}{l}\text { De Jong et al } \\
\text { (2005) }\end{array}$ \\
\hline & $\begin{array}{l}\text { Performance, egg } \\
\text { quality, and bone } \\
\text { strength }\end{array}$ & Laying hens & $\begin{array}{l}\text { The split feeding system showed a potential strategy to improve shell } \\
\text { quality by offering a better match between Ca supplementation and } \\
\text { requirements in the laying hen }\end{array}$ & $\begin{array}{l}\text { Molnár et al } \\
\text { (2018) }\end{array}$ \\
\hline & $\begin{array}{l}\text { Performance, eggshell } \\
\text { quality, incubation } \\
\text { traits, and behavior }\end{array}$ & Laying hens & $\begin{array}{l}\text { Twice a day feeding improves behavior and split feeding improves } \\
\text { both egg production and behavior in broiler breeders. However, no } \\
\text { effects were observed on eggshell quality and incubation traits }\end{array}$ & $\begin{array}{l}\text { van Emous } \\
\text { et al (2021) }\end{array}$ \\
\hline
\end{tabular}


Balanced dietary electrolyte, i.e., $\mathrm{Na}, \mathrm{K}$, and $\mathrm{Cl}$, is generally considered a major factor influencing the quality of litter and the severity of FPD in broiler chickens. Several studies on broiler chickens and turkey reported that a high level of the dietary electrolyte leads to increase water intake that ultimately influences the litter quality and increases the incidence of FPD, and in some cases, enhances the severity (Koreleski et al 2010; Jankowski and Zdunczyk 2014). However, another study reported a higher incidence of FPD in growing female turkeys when fed with $0.25 \%$ additional sodium in diet (Lichtorowicz et al 2012). Similarly, when broiler chickens were fed with a $1.45 \%$ potassium level, it negatively affects litter quality and enhances the incidence and severity of FPD (Fuhrmann and Kamphues 2016). Dietary protein concentration is the second main factor that can affect litter quality and FPD severity. The studies on commercial broilers reported that birds fed with all vegetable protein sources had the highest incidence of FPD than those of having mixed protein (animal + vegetable protein source) in their diet (Cengiz et al 2013; Hossain et al 2013). Similarly, another study noted a higher incidence of FPD in broiler chickens when fed with corn and soybean meal diet than the birds fed with diet have the inclusion of poultry by-product meal (Eichner et al 2007). A study concluded that providing optimal dietary electrolytes, protein source, biotin, and some feed additive in the diet of broiler chickens and turkey could reduce the incidence and severity of FPD (Swiatkiewicz et al 2017).

The most common strategy for broiler breeders is feed restriction that is being practiced all around the globe. Provision of 2-2.5 hours of feeding and prolonged restriction could be helpful during the production stage to optimize the bird's body weight, reduce the chance for fat deposition on female reproductive traits and facilitate egg production (Nielsen et al 2011). However, feed restriction could be associated with aggression and severe feather pecking, especially on the tail and vent, leading to cannibalism in advanced stages (Strochlic and Romero 2008). Generally, a feather score is a major indicator for determining a bird's health. It is common to measure feather coverage score, feeding motivation, and stress response to make an ideal dietary strategy in broiler breeders (Arrazola and Torrey 2019). Feed restriction in poultry is considered controversial due to remaining feed motivation and from a welfare point of view as not fulfilling one of the five-freedom systems, i.e., birds should be free from hunger (van Krimpen and De Jong 2014; Tolkamp and D'Eath 2016). Thus, the latest dietary strategies supported higher satiety and reduced hunger with the increased feed allotment by diluting feed contents (qualitative feed restriction) of broiler diets (van Emous et al 2015).

\subsection{Effect of dietary strategies on bird's production performance}

The requirement of animal protein fulfillment for the fast-growing human population provoked scientists to genetically select the chickens for a higher growth rate. This selection, on one side, improved the adult body weight and increased the level of appetite in boilers and broiler breeders (Zuidhof et al 2014). It has been observed that offering ad libitum feed to broiler breeders causes a reduction in egg production and increases mortality with age (Renema and Robinson 2004). It is mandatory to restrict feeding to avoid excessive body weight, maintain reproductive capacity and health in broiler breeders. As improved genetic progress for higher body weight and increased nutrient requirements of modern broilers demand more feed restriction in broilers, it was restricted to $25-33 \%$ of required ad-libitum feed (De Jong et al 2002a).

Usually, eggs are laid early in the morning (Zakaria et al 2005; Zakaria and Omar 2013), and after 1 hour of laying, the next ovulation occurs (Etches 1987). Egg formation starts up with 6 hours of albumen formation in which protein and amino acids are involved (Leeson and Summers 2005). After 18 hours, calcium is required for the formation of eggshells. The nutrients are unavailable during the eggshell formation because the morning feed is digested 4-5 hours before shell formation; to fulfill this requirement, nutrients are deducted from the bone (Bar 2008). Suppose the daily required amount of feed is offered in a twice a day feeding strategy by dividing into two portions, then, it could increase the availability of nutrients for eggshell deposition and egg formation (Farmer et al 1983a), which ultimately improve Ca's utilization (Farmer et al 1983b; Roland and Farmer 1984). It has been observed that offering feed twice a day can improve the eggshell weight (Lewis and Perry 1988), and the number of eggs produced by broiler breeder females can also be improved (Taherkhani et al 2010; Moradi et al 2013; Soltanmoradi et al 2013).

On the other hand, some researchers observed no effect of twice a day feeding strategy on the eggshell thickness, eggshell weight (Samara et al 1996), and the number of eggs produced (De Avila et al 2003; Backhouse and Gous 2005; Londero et al 2015, 2016). It has been reported that feeding a standard diet twice a day did not affect the overall egg production (Samara et al 1996; De Avila et al 2003; Backhouse and Gous 2005; Londero et al 2015, 2016). However, on the other hand, improvement in egg production while feeding a standard diet twice a day has also been observed (Taherkhani et al 2010; Moradi et al 2013; Soltanmoradi et al 2013). Overall reviewing the previous studies, the older literature explained that twice a day feeding strategy did not alter the egg production except (Londero et al 2015, 2016), while the recent studies (onward from 2008) showed higher egg production in breeders fed twice a day. This inconsistency between different studies might be caused by their genetic differences explained by (van Emous and Mens 2021). Compared with the broiler breeders four decades ago, current broiler breeders have higher growth and production potential, which resulted in longer fasting durations and increased feed restrictions (De Jong and van Emous 2017). The prolonged fasting durations may negatively influence the hypothalamus regarding reduced gonadotropin secretion, which ultimately negatively 
affects ovulation, leading to reduced egg production (Morris and Nalbandov 1961). As far as the commercial layer is concerned, split feeding strategies in organic farming (van Krimpen et al 2018) and aviary system (Molnár et al 2018) did not affect egg production. Twice a day feeding system did not also affect the egg weight of commercial layers (Samara et al 1996; Backhouse and Gous 2005; Soltanmoradi et al 2013; Londero et al 2015, 2016). However, the other studies on breeders claim the contrary findings in which twice a day feeding strategy positively influenced the egg weight (Spradley et al 2008; Taherkhani et al 2010; Moradi et al 2013). The variation in the literature finding might be due to the variation in the length of experimental duration, explained by (van Emous and Mens 2021).

\subsection{Effect of dietary strategies on the bird's behavior}

It has been observed that the concentration of plasma corticosterone is improved due to increased feed restriction (Mormede et al 2007). The increase in plasma corticosterone might be associated with behavioral stress and adaptive metabolic adjustment to cope with the lower level of energy supply. Furthermore, stress and fasting may affect chickens' metabolism and immune response (Sherlock et al 2012). Some strategies are being considered to decrease negative behavioral parameters associated with restricted feeding, like the scattering of feed on bedding material, environmental enrichment, and restricted daily feeding. These strategies help the chickens regarding the availability of object stimuli and the natural habit of forage and pecking (De Jong et al 2005; Leone and Estevez 2008). Zuidhof et al (1995) suggested that the negative impact of feed restriction on welfare can be managed by diluting the diet's nutrient density.

A significant effect has been observed on the behavior of chickens when comparing once and twice a day feeding strategies. Chickens spent less time on object pecking and foraging and more time sitting and eating when fed twice a day. Although the amount of feed is the same while feeding twice a day, spending more time eating might be due to calm eating behavior. Furthermore, the chickens fed twice were observed less active as they spent more time sitting, standing, and resting which showed comfort (van Emous and Mens 2021). Previously, it has been reported that pullets showed less sitting, resting, and comfort when reared on restricted feeding, which might be caused by higher satiety and lover state of hunger (Hocking et al 1996). De Jong et al (2003) indicated that increased standing behavior of chickens is associated with an increase of eagerness of meal which reflects its state of hunger. When fed twice a day via scatter feed or trough, it has been reported that pullets caused more walking behavior (De Jong et al 2005). The difference in the behavior of chickens when fed twice a day is attributed to the difference in the level of feed restriction during the rearing and laying period (van Emous and Mens 2021). It has also been observed that chickens spent less time on foraging and object pecking when fed twice a day (van der Haar and van
Voorst 2001; De Jong et al 2005; van Emous and Mens 2021). In another study, a reduced level of object pecking was observed when broiler breeders fed twice a day, reflecting less frustration (Savory et al 1996; De Jong et al 2002b). During the rearing period, especially the stereotypic object pecking was observed, which was hardly observed during the laying phase (Sandilands et al 2005; De Jong et al 2005; van Emous et al 2015), which might be due to the higher amount of feeding during laying phase (van Emous and Mens 2021). The lower level of object pecking in birds fed twice a day is explained as eating time cannot be spent on other activities such as object pecking (Mason et al 2006; van Emous et al 2015; van Emous and Mens 2021).

Higher feeding frequency is associated with feeding, including feeding anticipation, standing, and comfort, which stimulated the chickens to perform object pecking (Dawkins 1989). Domestic chickens spend more time pecking (Dawkins 1989) because they usually explore the environment by using their beaks to forage (Schütz and Jensen 2001). Chickens feel more saturation when feed is offered throughout the day as feed is consistently present in the gastrointestinal tract, and satiety may cause reduced need to peck; meanwhile, pecking is the natural behavior repertoire of chickens to find and eat (Hetland et al 2004). van Emous and Mens (2021) observed that feeding birds twice a day had a positive influence on their behavior, as birds spent very little time drinking and eating in the afternoon when they were treated with once a day feeding. Furthermore, the chickens spent less time drinking and eating when fed twice a day because only $50 \%$ of daily feed was offered in the morning. Offering feed once a day influences resting behavior at the end of the day, which can be detrimental to fertilization and mating processes. Most matings are usually done at the end of the day (Harris et al 1980; Bilcik and Estevez 2005). Twice a day feeding strategy positively influenced mating activity and egg fertilization (van Emous and Mens 2021).

\section{Final Considerations}

Environmental conditions such as lighting, density, and dietary, have become critical factors in poultry farming particularly with the current climate and economic challenges. The current review focuses on recent advances in poultry house lighting, density, and dietary factors. These factors can potentially affect the whole bird's life and interest traits. Light management, for example, has a significant impact on birds beginning with incubation and continuing through marketing. They do not affect only birds' development and growth but can also have long-lasting effects on birds' behavior and welfare. This review also presents different practical strategies that could be successful used to ameliorate heat stress on birds in some tropical and subtropical regions. Good management and optimal husbandry programs enhance birds' behavior (activities), health (immunity), productive performance (feed intake, body weight, among others) as well as welfare, resulting in more profitable production. 


\section{Acknowledgements}

All the authors of this manuscript are grateful to their respective universities for their technical assistance and valuable support in completing this review.

\section{Conflict of Interest}

The authors have no conflicts of interest related to the present review.

\section{Funding}

This research did not receive any financial support.

\section{References}

Abo Alqassem Z, Ahmed S, Ahmed E, El Iraqi K (2018) Effect of different stocking densities as an environmental stressing factor on broiler behavior and performance. Benha Veterinary Medical Journal 34:51-65.

Abo Ghanima MM, Abd El-Hack ME, Taha AE, Tufarelli V, Laudadio V, Naiel MAE (2020) Assessment of stocking rate and housing system on performance, carcass traits, blood indices, and meat quality of french pekin ducks. Agriculture 10:273.

Abudabos AM, Samara EH, Elsayad OS, Al-Atiyat RM, Al-Haidary A (2013) Influence of stocking density on welfare indices of broilers. Italian Journal of Animal Science 12: e35.

Albentosa MJ, Cooper JJ, Luddem T, Redgate SE, Elson HA, Walker AW (2007) Evaluation of the effects of cage height and stocking density on the behaviour of laying hens in furnished cages. British Poultry Science 48:1-11.

Aldridge DJ, Scanes CG, Kidd MT (2021) Performance and preference of broilers provided dual light warmth. Journal of Applied Poultry Research 30:100187

Andrews SM, Omed HM, Phillips CJC (1997) The effect of a single or repeated period of high stocking density on the behavior and response to stimuli in broiler chickens. Poultry Science 76:1655-1660.

Archer GS (2018) Effect of two different commercially available white light LED fixtures on broiler hatchability and chick quality. British Poultry Science 59:251-255.

Arrazola A, Torrey S (2019) The development of fault bars in domestic chickens (Gallus gallus domesticus) is affected by acute stressors. Animal Welfare 28:279-286.

Astaneh IY, Chamani M, Mousavi SN, Sadeghi AA, Afshar MA (2018) Effects of Stocking Density on Performance and Immunity in Ross 308 Broiler Chickens. Kafkas Universitesi Veteriner Fakultesi Dergisi 24 (4):483-489.

Backhouse D, Gous RM (2005) The effect of feeding time on shell quality and oviposition time in broiler breeders. British Poultry Science 46:255-259.

Baeza E, Chartrin P, Arnould C (2003) Effects of stocking density on welfare, growth performance and carcass quality in Muscovy ducks. Sciences et Techniques Avicoles 45:4-8

Bar A (2008) Calcium homeostasis and vitamin D metabolism and expression in strongly calcifying laying birds. Comparative Biochemistry \& Physiology 151:477-490.

Beilmann T, Thaxton J, Dozier III W, Roush W, Miles D, Lott B, Vizzier-Thaxton $Y(2005)$ Evaluation of stocking density on eating and drinking behavior of broilers. Poultry Science 84(S1):100.

Berg C, Yngvesson J (2012) Optimal stocking density for broilers Optimal for whom? In XXIVWorld Poultry Congress, Area: Poultry Welfare and Environment 5-9 August 2012, Salvador, Bahia, Brazil.

Bilcik B, Estevez I (2005) Impact of male-male competition and morphological traits on mating strategies and reproductive success in broiler breeders. Applied Animal Behaviour Science 92:307-323.

Borille R, Garcia RG, Naas IA, Caldara FR, Santana MR (2015) Monochromatic light-emitting diode (LED) source in layers hens during the second production cycle. Revista Brasileira de Engenharia Agrícola e Ambiental 19:877-881.
Buyse J, Simons PCM, Boshouwers FMG, Decuypere E (1996) Effect of intermittent lighting, light intensity and source on the performance and welfare of broilers. World's Poultry Science Journal 52:121-130.

Campo JL, Gil MG, Davila SG, Munoz I (2007) Effect of lighting stress on fluctuating asymmetry, heterophil-to-lymphocyte ratio, and tonic immobility duration in eleven breeds of chickens. Poultry Science 43:355-363.

Cao J, Wang Z, Dong Y, Zhang Z, Li J, Li F, Chen Y (2012) Effect of combinations of monochromatic lights on growth and productive performance of broilers. Poultry Science 91:3013-3018.

Cengiz O, Koksal BH, Tatlı O, Sevim O, Ahsan U, Uner AG, Ulutas PA, Beyaz D, Buyukyoruk S, Yakan A, Onol AG (2015) Effect of dietary probiotic and high stocking density on the performance, carcass yield, gut microflora, and stress indicators of broilers. Poultry Science 94:2395-2403.

Cengiz O, Hess JB, Bilgili SF (2013) Effect of protein source on the development of footpad dermatitis in broiler chickens reared on different flooring types. Archiv fur Geflugelkunde 77:166-170.

Chegini S, Kiani A, Rokni H (2018) Alleviation of thermal and overcrowding stress in finishing broilers by dietary propolis supplementation. Italian Journal of Animal Science 17:377-385.

Dawkins MS (2018) Stocking density: Can we judge how much space poultry need? in Mench JA (ed.) Advances in Poultry Welfare (pp. 227-242). London: Woodhead Press.

Dawkins MS, Donnelly C, Jones T (2004) Chicken welfare is influenced more by housing conditions than by stocking density. Nature 427:342-344.

Dawkins MS (1989) Time budgets in red junglefowl as a baseline for the assessment of welfare in domestic fowl. Applied Animal Behaviour Science 24:77-80

De Avila VS, Penz JrAM, de Brum PAR, Rosa PS, Guidoni AL, de Figueiredo ÉAP (2003) Performance of female broiler breeders submitted to different feeding schedules. Brazilian Journal of Poultry Science 5:197-201.

De Jong IC, van Emous RA (2017) Broiler breeding flocks: management and animal welfare. Pages 211-230 in Achieving sustainable production of poultry meat. T. Applegate, ed. Burleigh Dodds Sci. Publ. Lim., Sawston, Cambridge, UK.

De Jong IC, Fillerup M, Biokhuis HJ (2005) Effect of scattered feeding and feeding twice a day during rearing on indicators of hunger and frustration in broiler breeders. Applied Animal Behaviour Science 92:61-76.

De Jong IC, van Voorst S, Blokhuis HJ (2003) Parameters for quantification of hunger in broiler breeders. Physiology \& Behavior 78:773-783.

De Jong IC, Van Voorst S, Ehlhardt DA, Blokhuis HJ (2002a) Effects of timing and durations of feed restriction during rearing on reproductive characteristic in broiler breeder females. Poultry Science 78:1424-1434.

De Jong IC, van Voorst S, Ehlhardt DA, Blokhuis HJ (2002b) Effects of restricted feeding on physiological stress parameters in growing broiler breeders. British Poultry Science 43:157-168.

De Jong IC, Van Harn J, Gunnink H, Hindle VA, Lourens A (2012) Footpad dermatitis in Dutch broiler flocks: prevalence and factors of influence. Poultry Science 91: 1569-1574.

Deep A, Schwean-Lardner KV, Crowe TG, Fancher BI, Classen HL (2012) Effect of light intensity on broiler behaviour and diurnal rhythms. Applied Animal Behaviour Science 136:50-56.

Dozier WA III, Thaxton JP, Branton SL, Morgan GW, Miles DM, Roush WB, Lott BD, Vizzier-Thaxton $Y$ (2005) Stocking density effects on growth performance and processing yields of heavy broilers. Poultry Science 84:1332-1338.

Dozier WA III, Thaxton JP, Purswell JL, Olanrewaju HA, Branton SL, Roush WB (2006) Stocking density effects on male broilers grown to 1.8 kilograms of body weight. Poultry Science 85:344-351.

Drozdová A, Kaňková Z, Bilčík B, Zeman M (2021) Prenatal effects of red and blue light on physiological and behavioural parameters of broiler chickens. Czech Journal of Animal Science 66:412-419.

Eichner G, Vieira SL, Torres CA, Coneglian JLB, Freitas DM, Oyarzabal OA (2007) Litter moisture and footpad dermatitis as affected by diets 
formulated on an all-vegetable basis or having the inclusion of poultry byproduct. Journal of Applied Poultry Research 16:344-350.

Elkomy HE, Taha AE, Basha HA, Abo-Samaha MI, Sharaf MM (2019) Growth and reproduction performance of Japanese quails (Coturnix coturnix japonica) under various environments of light colors. Slovenian Veterinary Research 56:119-127.

Erisir M, Erisir Z (2002) Yerleflim sıklı.ı arttırılan bıldırcınların (Coturnix coturnix japonica) bazı biyokimyasal kan parametrelerindeki de.ifliklikler. Turkish Journal of Veterinary and Animal Science 26:491-496.

Etches RJ (1987) Calcium logistics in the laying hen. The Journal of Nutrition 117:619-628.

Farmer M, Roland SrDA, Brake J, Eckman MK (1983a) Calcium metabolism in broiler breeder hens. 1. Calcium status of the digestive tract of broiler breeders throughout a 24 hour period. Poultry Science 62:459-464.

Farmer M, Roland SrDA, Eckman MK (1983b) Calcium metabolism in broiler breeder hens. 2 . The influence of the time of feeding on calcium status of the digestive system and egg shell quality in broiler breeders. Poultry Science 62:465-471.

Fawcett DL, Casey-Trott TM, Jensen L, Caston LJ, Widowsk TM (2020) Strain differences and effects of different stocking densities during rearing on the musculoskeletal development of pullets. Poultry Science 99: 4153-4161.

Feddes JJR, Emmanuel EJ, Zuidhof MJ (2002) Broiler performance, body weight variance, feed and water intake,and carcass quality at different stocking densities. Poultry Science 81:774-779.

Fernández-Juricic E, Erichsen JT, Kacelnik A (2004) Visual perception and social foraging in birds. Trends in Ecology \& Evolution 19:25-31.

Fuhrmann R, Kamphues J (2016) Effects of fat content and source as well as of calcium and potassium content in the diet on fat excretion and saponification, litter quality and foot pad health in broilers. European Poultry Science 80:1-12.

Gomes AVS, Quinteiro-Filho WM, Ribeiro A, Ferraz-de-Paula V, Pinheiro ML, Baskeville E, Akamine AT, Astolfi-Ferreira CS, Ferreira AJ, Palermo-Neto J (2014) Overcrowding stress decreases macrophage activity and increases Salmonella enteritidis invasion in broiler chickens. Avian Pathology 43:82-90.

Hall A (2001) The effect of stocking density on the welfare and behaviour of broiler chickens reared commercially. Animal Welfare 10:23-40.

Harris GCJr, Benson J, Sellers R, Cole TA (1980) The mating activity of broiler breeder cockerels. Arkansas Farm \& Ranch Resources 29:15.

Heckert RA, Estevez I, Russek-Cohen E, Pettit-Riley R (2002) Effects of density and perch availability on the immune status of broilers. Poultry Science 81:451-457.

Hesham MH, El-Shereen AH, Enas SN (2018) Impact of different light colors in behavior, welfare parameters and growth performance of Fayoumi broiler chickens strain. Journal of the Hellenic Veterinary Medical Society 69:951958.

Hetland H, Choct M, Svihus B (2004) Role of insoluble non-starch polysaccharides in poultry nutrition. World's Poultry Science Journal 60:415422.

Hocking PM, Maxwell MH, Mitchell MA (1996) Relationships between the degree of food restriction and welfare indices in broiler breeder females. British Poultry Science 37:263-278.

Hofmann T, Schmucker S, Grashorn M, Stefanski V (2021) Short- and longterm consequences of stocking density during rearing on the immune system and welfare of laying hens. Poultry Science 100:101243.

Hossain MA, Islam AF, Iji PA (2013) Growth responses, excreta quality, nutrient digestibility, bone development and meat yield traits of broiler chickens fed vegetable or animal protein diets. South African Journal of Animal Science 43: 208-218.

Houshmand M, Azhar K, Zulkifli I, Bejo M, Kamyab A (2012) Effects of prebiotic, protein level, and stocking density on performance, immunity, and stress indicators of broilers. Poultry Science 91: 393-401.

Huo X, Na-Lampang P (2016) Effects of stocking density on feather pecking and aggressive behavior in Thai crossbred chickens. Agriculture and Natural

\section{Resources. 50: 396-399.}

Husveth F, Pal L, Galamb E, Acs KC, Bustyahazai L, Wagner L, Dublecz F, Dublecz K (2015) Effects of whole wheat incorporated into pelleted diets on the growth performance and intestinal function of broiler chickens. Anim. Feed Sci. Technol. 210:144-151.

Huth JC, Archer GS (2015) Comparison of Two LED Light Bulbs to a Dimmable CFL and their Effects on Broiler Chicken Growth, Stress, and Fear. Poultry Science 94: 9, 2027-2036.

Iyasere OS, Daramola JO, Bemji MN, Adeleye OO, Sobayo RA, lyasere E, Onagbesan OM (2012) Effects of stocking density and air velocity on behaviour and performance of Anak broiler chickens in South-Western Nigeria. Int. J. Appl. Anim. Sci. 1:52-56.

Jankowski J, Zdunczyk Z (2014) The effect of dietary sodium chloride concentrations on blood electrolyte concentrations, the incidence of foot pad dermatitis and bone mineralization in broiler chickens and turkeys. Journal of Elementology 19:265-275.

Jobe MC, Ncobela CN, Kunene NW, Opoku AR (2019) Effects of Cassia abbreviata extract and stocking density on growth performance, oxidative stress and liver function of indigenous chickens. Tropical Animal Health and Production 51:2567-2574.

Koreleski J, Swiatkiewicz S, Arczewska A (2010) The effect of dietary potassium and sodium on performance, carcass traits, and nitrogen balance and excreta moisture in broiler chicken. Journal of Animal and Feed Sciences 19:244-256.

Kryeziu AJ, Mestani N, Berisha Sh, Kamberi MA (2018) The European performance indicators of broiler chickens as influenced by stocking density and sex. Agronomy Research 16(2):483-491.

Leeson S, Summers JD (2005) Commercial Poultry Nutrition. $3^{\text {rd }}$ Edition. University Books, Guelph, Ontario, Canada.

Leone EH, Estevez I (2008) Economic and welfare benefits of environmental enrichment for broiler breeders. Poultry Science 87:14-21.

Lewis PD, Perry GC (1988) Effect of a single or double daily allocation of food on shell weight and oviposition time of broiler breeder hens. Pages 72-78 in Proceedings of the Fourth International Poultry Breeders Conference. The West of Scotland College, Ayr, Scotland.

Lewis PD, Gous RM (2009) Responses of poultry to ultraviolet radiation. World's Poultry Science Journal 65:499-510.

Lewis PD, Morris TR (2006) Poultry Lighting- The Theory and Practice. Nottingham Univ. Press, Nottingham, UK.

Li G, Ji B, Li B, Shi Z, Zhao Y, Dou Y, Brocato J (2020) Assessment of layer pullet drinking behaviors under selectable light colors using convolutional neural network. Computers and Electronics in Agriculture 172:105333.

Li G, Li B, Zhao Y, Shi Z, Liu Y, Zheng W (2019) Layer pullet preferences for light colors of light-emitting diodes. Animal 13:1245-1251.

Li G, Zhao Y, Purswell J, Chesser G, Lowe JW, Wu TL (2020) Effects of antibiotic-free diet and stocking density on male broilers reared to 35 days of age. Part 2: feeding and drinking behaviors of broiler. Journal of Applied Poultry Research 29:391-401.

Li G, Zhao Y, Chesser D, Lowe JW, Purswell JL (2019) Image processing for analyzing broiler feeding and drinking behaviors. ASABE Annual International Meeting, July 7-10 July 2019, Boston, Massachusetts, USA, p. 1900165.

Lichtorowicz K, Jankowski J, Zdunczyk Z, Juskiewicz J (2012) The effect of different dietary sodium levels on blood electrolytes, growth performance and foot pad dermatitis incidence in turkeys. Journal of Elementology 17:279-287.

Ligaraba TJ, Benyi K, Baloyi JJ (2016) Effects of genotype and stocking density on broiler performance under three feeding regimes. Tropical Animal Health and Production 48:1227-1234.

Liu K, Xin H, Sekhon J, Wang T (2018) Effect of fluorescent vs. poultry-specific light-emitting diode lights on production performance and egg quality of $\mathrm{W}$ 36 laying hens. Poultry Science 97:834-844.

Londero A, Rosa AP, Giacomini CBS, Vivas CEB, Orso C, de Freitas HM, Gressler LT, Vargas AC (2015) Effect of different feeding schedules on 
reproductive parameters and egg quality of broiler breeders. Animal Feed Science and Technology 210:165-171

Londero A, Rosa AP, Vivas CEB, Orso C, Fernandes MO, Paixão SJ, Giacomini CBS, Andrade CM, Palma HE (2016) The effect of different feeding schedules on egg quality, blood and bone parameters in broiler breeders. Animal Reproduction 13:14-20.

Mahrose KM, Alagawany M, Abd Elhack ME, Mahgoub SA, Attia FAM (2019) Influences of stocking density and dietary probiotic supplementation on growing Japanese quail performance. Anais da Academia Brasileira de Ciências 91(2): e20180616.

Mason G, Clubb R, Latham N, Vickery S (2006) Why and how should we use environmental enrichment to tackle stereotypic behavior? Applied Animal Behaviour Science 102:163-188.

Maty HN, Ahmed SM, Hassan AA (2021) Impact of different artificial light intensities on some reproductive, productive performance aspects and blood picture of male quail. Iraqi Journal of Veterinary Sciences 35:679-685.

Meluzzi A, Fabbri C, Folegatti E, Sirri F (2008) Survey of chicken rearing conditions in Italy: effects of litter quality and stocking density on productivity, foot dermatitis and carcase injuries. British Poultry Science 49:257-264

Mohamed RA, Eltholth MM, El-Saidy NR (2014) Rearing broiler chickens under monochromatic blue light improve performance and reduce fear and stress during pre-slaughter handling and transportation. Biotechnology in Animal Husbandry 30:457-471.

Molnár A, Kempen I, Sleeckx N, Zoons J, Maertens L, Ampe B, Buyse J, Delezie E (2018) Effects of split feeding on performance, egg quality, and bone strength in brown laying hens in aviary system. Journal of Applied Poultry Research 27:401-415

Moradi S, Zaghari M, Shivazad M, Osfoori R, Mardi M (2013) The effect of increasing feeding frequency on performance, plasma hormones and metabolites, and hepatic lipid metabolism of broiler breeder hens. Poultry Science 92:1227-1237.

Moreira J, Mendes AA, Roca RO, Garcia EA, Naas IA, Garcia RG, Lima IC, Paz A (2004) Effect of stocking density on performance, carcass yield and meat quality in broilers of different commercial strains. Revista Brasileira de Zootecnia 33: 1506-1519.

Mormede P, Andanson S, Auperin B, Beerda B, Guemene D, Malnikvist J, Manteca X, Manteufeel G, Prunet P, Van Reenen CG, Richard S, Veissier (2007) Exploration of the hypothalamic-pituitary-adrenal function as a tool to evaluate animal welfare. Physiology \& Behavior 92:317-339.

Morris TR, Nalbandov AV (1961) The induction of ovulation in starving pullets using mammalian and avian gonadotropins. Endocrinology 68:687-697.

Najafi P, Zulkifli I, Jajuli NA, Farjam AS, Ramiah SK, Amir AA, O’Reily E, Eckersall D (2015) Environmental and stocking density effects on actute phase proteins, heat shock protein 70 , circulating corticosterone and performance in broiler chickens. International Journal of Biometeorology 59:1577-1583.

Nasr MAF, Alkhedaide AQ, Ramadan AAI, Hafez A-ESE, Hussein MA (2021) Potential impact of stocking density on growth, carcass traits, indicators of biochemical and oxidative stress and meat quality of different broiler breeds. Poultry Science 100(11):101442.

Nielsen BL, Thodberg K, Malmkvist J, Steenfeldt S (2011) Proportion of insoluble fibre in the diet affects behaviour and hunger in broiler breeders growing at similar rates. Animal 5:1247-1258.

Nogueira WCL, Velasquez PAT, Furlan RL, Macari M (2013) Effect of dietary energy and stocking density on the performance and sensible heat loss of broilers reared under tropical winter conditions. Brazilian Journal of Poultry Science 15:53-57.

Obeidat MD, Al-Tamimi H, Nusairat B, Obeidat BS (2019) Effect of breed and density on growth performance and carcass traits of two broiler breeds. International Congress on Agriculture and Forestry research, 8-10 April 2019, Marmaris, Turkey.

Oke OE, Oso OE, Iyasere OS, Oni A, Bakre O, Rahman S (2021a) Evaluation of light color manipulation on behavior and welfare of broiler chickens. Journal of Applied Animal Welfare Science 2021:1-12.

Oke OE, Oni A, Adebambo PO, Oso OM, Adeoye MM, Lawal T, Afolayan T, Ogunbajo OE, Ojelade DI, Bakre OA, Daramola JO, Smith OF (2021b) Evaluation of light colour manipulation on physiological response and growth performance of broiler chickens. Tropical Animal Health and Production 53:6.

Olanrewaju HA, Miller WW, Maslin WR, Collier SD, Purswell JL, Branton SL (2018) Influence of light sources and photoperiod on growth performance, carcass characteristics, and health indices of broilers grown to heavy weights. Poultry Science 97:1109-1116.

Olanrewaju HA, Purswell JL, Collier SD, Branton SL (2016) Effects of light sources and intensity on broilers grown to heavy weights: Hematophysiological and biochemical assessment. International Journal of Poultry Science 15:384-393.

Osman AMA (1993) Effect of stocking rate on growth performance, carcass traits and meat quality of male Peking ducks. Journal of Agriculture and Rural Development in the Tropics and Subtropics 94:147-156.

Pal P, Dey DK, Sharma B, Choudhary SK, Sahu J, Kumar S, Ghosh S (2019) Effect of light management in broiler production: A review. Journal of Entomology and Zoology Studies 7:437-441.

Palizdar MH, Daylami MK, Pourelmi MR (2017) Effects of high stocking density on growth performance, blood metabolites and immune response of broilers (Ross 308). Journal of Livestock Science 8:196-200.

Pan J, Yang Y, Yang B, Yu Y (2014) Artificial polychromatic light affects growth and physiology in chicks. PloS One 9: e113595.

Parvin R, Mushtaq MMH, Kim MJ, Choi HC (2014) Light emitting diode (LED) as a source of monochromatic light: a novel lighting approach for behaviour, physiology and welfare of poultry. World's Poultry Science Journal 70:543556.

Patel SJ, Patel AS, Patel MD, Patel JH (2016) Significance of Light in Poultry Production: A Review. Advances in Life Sciences 5:1154-1160.

Petek M, Ustuner H, Yesilbag D (2014). Effects of stocking density and litter type on litter quality and growth performance of broiler chicken. Kafkas Universitesi Veteriner Fakultesi Dergisi 20:743-748.

Prescott NB, Wathes CM, Jarvis JR (2003) Light, vision and welfare of poultry. Animal Welfare 12:269-288.

Qaid M, Albatshan H, Shafey T, Hussein E, Abudabos AM (2016) Effect of stocking density on the performance and immunity of 1- to 14-d old broiler chicks. Brazilian Journal of Poultry Science 18:683-691.

Raccoursier M, Thaxton YV, Christensen K, Aldridge DJ, Scanes CG (2019) Light intensity preferences of broiler chickens: implications for welfare. Animal 13: 2857-2863.

Rana MS, Campbell DLM (2021) Application of ultraviolet light for poultry production: a review of impacts on behavior, physiology, and production. Frontiers in Animal Science 2:699262.

Ravindran V, Thomas DV, Thomas DG, Morel PC (2006) Performance and welfare of broilers as affected by stocking density and zinc bacitracin supplementation. Animal Science Journal 77:110-116.

Reiter K, Bessei W (2000) Effect of stocking density of broilers on temperature in the litter and at bird level. Archiv fur Geflugelkunde 64:204206.

Ren G, Lin T, Ying Y, Chowdhary G, Ting KC (2020) Agricultural robotics research applicable to poultry production: A review. Computers and Electronics in Agriculture 169:105216.

Renema RA, Robinson FE (2004) Defining normal: comparison of feed restriction and full feeding of female broiler breeders. World's Poultry Science Journal 60:511-525.

Rodenburg TB, Bracke MBM, Berk J, Cooper J, Faure JM, Guémené D, Guy G, Harlander A, Jones T, Knierim U, Kuhnt K, Pingel H, Reiter K, Servière J, Ruis MAW (2005) Welfare of ducks in European duck husbandry systems. World's Poultry Science Journal 61:633-646.

Roland DA, Farmer M (1984) Egg shell quality II: importance of time of calcium intake with emphasis on broiler breeders. World's Poultry Science 


\section{Journal 40:255-260}

Sabuncuoglu KM, Korkmaz F, Gurcan EK, Narinc D, Samli HE (2018) Effects of monochromatic light stimuli during embryogenesis on some performance traits, behavior, and fear responses in Japanese quails. Poultry Science 97:2385-2390.

Sahin R, Kucukm O (2001) A simple way to reduce heat stress in laying hens as judged by egg laying, body weight gain and biochemical parameters. Acta Vetenarium Hungarcia 49:421-430.

Samara MH, Robbins KR, Smith MO (1996) Interaction of feeding time and temperature and their relationship to performance of the broiler breeder hen. Poultry Science 75:34-41.

Sandilands V, Tolkamp BJ, Kyriazakis I (2005) Behaviour of food restricted broilers during rearing and lay - effects of an alternative feeding method. Physiology \& Behavior 85:115-123.

Savory CJ, Hocking PM, Mann JS, Maxwell MH (1996) Is broiler breeder welfare improved by using qualitative rather than quantitative food restriction to limit growth rate? Animal Welfare 5:105-127.

Schütz KE, Jensen P (2001) Effects of resource allocation on behavioura strategies: A comparison of red jungle fowl (Gallus gallus) and two domesticated breeds of poultry. Ethology 107:753-765.

Senaratna D, Samarakone TS, Gunawardena WW (2016) Red color light at different intensities affects the performance, behavioral activities and welfare of broilers. Asian-Australasian Journal of Animal Science 29:1052 1059.

Seo HS, Kang M, Yoon RH, Roh JH, Wei B, Ryu KS, Cha SY, Jang HK (2016) Effects of various LED light colors on growth and immune response in broilers. The Journal of Poultry Science 53:76-81.

Sherlock L, Wathes MC, Cheng Z, Watches DC (2012) Differential hepatic gene expression in the broiler chicken in response to the combined stressors of food withdrawal, catching and transport at the end of production. International Journal on Biology of Stress 15:293-305.

Simitzis $P E$, Kalogeraki $E$, Goliomytis $M$, Charismiadou MA, Triantaphyllopoulos K, Ayoutanti A, Niforou K, Hager-Theodorides AL, Deligeorgis SG (2012) Impact of stocking density on broiler growth performance, meat characteristics, behavioural components and indicators of physiological and oxidative stress. British Poultry Science 53:721-730.

Simsek UG, Ciftci M, Cerci IH, Bayraktar M, Dalkilic B, Arslan O, Balci TA (2011) Impact of stocking density and feeding regimen on broilers: Performance, carcass traits and bone mineralization. Journal of Applied Poultry Research 39:230-233.

Skrbic Z, Pavlovski Z, Lukic M, Petricevic V (2015) Incidence of footpad dermatitis and hock burns in broilers as affected by genotype, lighting program and litter type. Annals of Animal Science 15:433-445.

Soliman FN, El-Sabrout K (2020) Light wavelengths/colors: Future prospects for broiler behavior and production. Journal of Veterinary Behavior 36:3439.

Soltanmoradi MG, Seidavi A, Dadashbeiki M, Delgado F, Gamboa S (2013) Effect of time, amount and frequency of feeding on total egg production, fertility and hatchability in broiler breeders. Archives Animal Breeding 56:102

Son JH (2013) The effect of stocking density on the behaviour and welfare indexes of broiler chickens. Journal of Agricultural Science and Technology 3:307-311.

Sorensen P, Su G, Kestin SC (2000) Effects of age and stocking density on leg weakness in broiler chickens. Poultry Science 79:864-870.

Spradley JM, Freeman ME, Wilson JL, Davis AJ (2008) The influence of a twice a-day feeding regimen after photostimulation on the reproductive performance of broiler breeder hens. Poultry Science 87:561-568.

Strochlic DE, Romero LM (2008) The effects of chronic psychological and physical stress on feather replacement in European starlings (Sturnus vulgaris). Comparative Biochemistry \& Physiology 149:68-79.

Su CH, Cheng C, Lin J, Liu H, Yu Y, Lin C, Chen W (2021) The effect of different colored light emitting diode (LED) illumination on Brown Tsaiya Duck egg laying performance, egg qualities, blood hormone levels and behavior patterns. Animal bioscience 34(11):1870-1878.

Su G, Sorensen P, Kestin SC (1999) Meal feeding is more effective than early feed restriction at reducing the prevalence of leg weakness in broiler chickens. Poultry Science 78:949-955.

Swiatkiewicz S, Arczewska-Wlosek A, Jozefiak D (2017) The nutrition of poultry as a factor affecting litter quality and foot pad dermatitis - an updated review. Journal of Animal Physiology and Animal Nutrition 101(5):14-20.

Taherkhani R, Zaghari M, Shivazad M, Zare Shahneh A (2010) A twice-a-day feeding regimen optimizes performance in broiler breeder hens. Poultry Science 89:1692-1702.

Thomas DG, Ravindran V, Thomas DV, Camden BJ, Cottam YH, Morel PCH, Cook CJ (2004) Influence of stocking density on the performance, carcass characteristics and selected welfare indicators of broiler chickens. New Zealand Veterinary Journal 52:76-81.

Toghyani M, Heidari S, Emadinia A (2016) Effect of stocking density and dietary sulfur amino acids on welfare indices of broiler chicks. Journal of Advanced Agricultural Technologies 3:124-127.

Tolkamp BJ, D'Eath RB (2016) Hunger associated with restricted feeding systems. In: Phillips C. (Ed.) Nutrition and the Welfare of Farm Animals. Animal Welfare, vol 16. Springer International Publishing.

van der Haar J, van Voorst S (2001) Welfare breeder pullets fed twice a day (in Dutch). Praktijkonderzoek Veehouderij - Pluimvee, Lelystad, The Netherlands. pp. 21-25.

van Emous RA, Mens AJW (2021) Effects of twice a day feeding and split feeding during lay on broiler breeder production performance, eggshell quality, incubation traits, and behavior. Poultry Science 100(11):101419.

van Emous RA, Kwakkel RP, van Krimpen MM, Hendriks WH (2015) Effects of different dietary protein levels during rearing and different dietary energy levels during lay on behaviour and feather cover in broiler breeder females. Applied Animal Behaviour Science 168:45-55.

van Emous RA, Kwakkel RP, Van Krimpen MM, van Den Brand H, Hendriks WH (2015) Effects of growth patterns and dietary protein levels during rearing of broiler breeders on fertility, hatchability, embryonic mortality, and offspring performance. Poultry Science 94:681-691.

van Krimpen MM, van Binnendijk GP, van Emous RA (2018) Effect of splitfeeding in organic layers on phosphorus excretion and eggshell quality (In Dutch). Wageningen Livestock Research Report 1120, Wageningen, The Netherlands.

van Krimpen M, De Jong IC (2014) Impact of nutrition on welfare aspects of broiler breeder flocks. World's Poultry Science Journal 70:139-150.

Wei Y, Zheng W, Li B, Tong Q, Shi H (2020) Effects of a two-phase mixed color lighting program using light-emitting diode lights on layer chickens during brooding and rearing periods. Poultry Science 99:4695-4703.

Weimer SL, Mauromoustakos A, Karcher DM, Erasmus MA (2020) Differences in performance, body conformation, and welfare of conventional and slow-growing broiler chickens raised at 2 stocking densities. Poultry Science 99:4398-4407.

Whitehead CC (2002) Nutrition and poultry welfare. World's Poultry Science Journal 58:349-356

Wilson M, Lindstrom SH (2011) What the bird brain tells the bird eye: the function of descending input to the avian retina. Visual Neuroscience 28:337350.

Xie M, Jiang Y, Tang J, Wen ZG, Huang W, Hou SS (2014) Effects of stocking density on growth performance, carcass traits, and foot pad lesions of White Pekin ducks. Poultry Science 93:1644-1648.

Yang Y, Jiang J, Pan J, Ying Y, Wang X, Zhang M, Lu M, Chen X (2016) The relationship of spectral sensitivity with growth and reproductive response in avian breeders (Gallus gallus). Scientific Reports 6:19291.

Zakaria AH, Omar OH (2013) Egg laying pattern, egg weight, body weight at hatch and sex ratio bias relative to oviposition time of young- and mid-age broiler breeders. Animal Reproduction Science 141:80-85. 
Zakaria AH, Plumstead PW, Romero-Sanchez H, Leksrisompong N, Osborne J, Brake J (2005) Oviposition pattern, egg weight, fertility, and hatchability of young and old broiler breeders. Poultry Science 84:1505-1509.

Zhao Z, Zou X, Yin Z, Cao Z, Zhang J, Wang C, Liu W, Bai Y (2021) Research on the correlation between breeding environment and activity of yellow feather broilers based on the multichromatic aberration model. Computational Intelligence and Neuroscience 2021:2897879.

Zuidhof MJ, Schneider BL, Carney VL, Korver DR, Robinson FE (2014) Growth, efficacy, and yield of commercial broiler from 1957, 1978, and 2005. Poultry Science 12:2970-2982.
Zuidhof MJ, Holm DE, Renema RA, Jalal MA, Robinson FE (2015) Effects of broiler breeder management on pullet body weight and carcass uniformity. Poultry Science 94:1389-1397.

Zuidhof MJ, Robinson FE, Feddes JJR, Hardin RT (1995) The effects of nutrient dilution on the well-being and performance of female broiler breeders. Poultry Science 74:441-456.

Zuowei S, Yan L, Yuan L, Jiao H, Song Z, Guo Y, Lin H (2011) Stocking density affects the growth performance of broilers in a sex-dependent fashion. Poultry Science 90:1406-1415. 